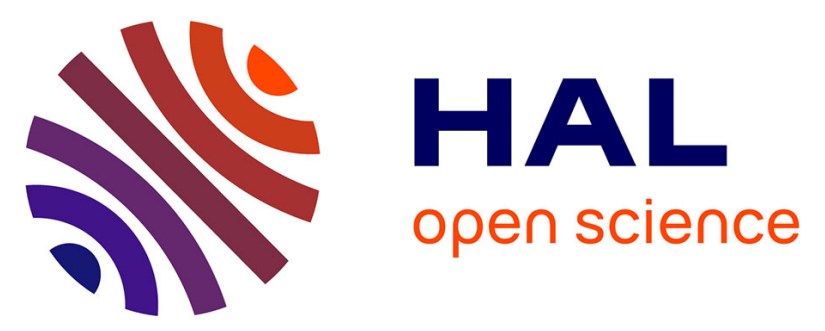

\title{
Importance of the Nature of the Active Acid/Base Pairs of Hydroxyapatite Involved in the Catalytic Transformation of Ethanol to $\mathrm{n}$-Butanol Revealed by Operando DRIFTS
}

Manel Ben Osman, Jean-marc Krafft, Cyril Thomas, Tetsuya Yoshioka, Jun Kubo, Guylène Costentin

\section{To cite this version:}

Manel Ben Osman, Jean-marc Krafft, Cyril Thomas, Tetsuya Yoshioka, Jun Kubo, et al.. Importance of the Nature of the Active Acid/Base Pairs of Hydroxyapatite Involved in the Catalytic Transformation of Ethanol to n -Butanol Revealed by Operando DRIFTS. ChemCatChem, 2019, 11 (6), pp.1765-1778. 10.1002/cctc.201801880 . hal-02168502

\section{HAL Id: hal-02168502 \\ https://hal.sorbonne-universite.fr/hal-02168502}

Submitted on 28 Jun 2019

HAL is a multi-disciplinary open access archive for the deposit and dissemination of scientific research documents, whether they are published or not. The documents may come from teaching and research institutions in France or abroad, or from public or private research centers.
L'archive ouverte pluridisciplinaire HAL, est destinée au dépôt et à la diffusion de documents scientifiques de niveau recherche, publiés ou non, émanant des établissements d'enseignement et de recherche français ou étrangers, des laboratoires publics ou privés. 


\title{
Importance of the Nature of the Active Acid / Base Pairs of
}

\section{Hydroxyapatite Involved in the Catalytic Transformation of}

\author{
Ethanol to $\boldsymbol{n}$-Butanol Revealed by Operando DRIFTS
}

\author{
Manel Ben Osman, ${ }^{[a]}$ Jean-Marc Krafft, ${ }^{[a]}$ Cyril Thomas, ${ }^{[a]}$ Tetsuya Yoshioka,${ }^{[b]}$ Jun Kubo, ${ }^{[b]}$ \\ and Guylène Costentin*
}

\begin{abstract}
Operando DRIFTS is used to identify the nature and the role of the surface sites of hydroxyapatites (HAps) involved in the catalytic transformation of ethanol to $n$-butanol. The surface processes occurring upon a first reaction step followed by a step under He flow greatly influence the reactivity of HAps in a subsequent second reaction step. Ethanol is found to be mostly activated by the basic $\mathrm{OH}^{-}$groups of HAps, as indicated by the concomitant recovery of ethanol conversion and $\mathrm{OH}^{-}$groups under He flow. The drastic changes in selectivity observed during the second reaction step reveal the key role of acidic sites cooperatively acting with basic sites for basic reaction steps. Once the $\mathrm{POH}$ groups are poisoned by extensive formation of polymeric carbon species and the $\mathrm{Ca}^{2+}$ sites are available, the production of acetaldehyde is drastically promoted at the expense of that of $n$-butanol. It is concluded that i) acetaldehyde acts as an intermediate in the formation of $n$-butanol, and ii) various active sites are involved in the key basic reaction steps such as $\mathrm{Ca}^{2+}-\mathrm{OH}^{-}$and $\mathrm{POH}-\mathrm{OH}^{-}$acid-base pairs in the dehydrogenation of ethanol to acetaldehyde and the aldol condensation for $n$-butanol formation, respectively.
\end{abstract}

\section{Introduction}

In the context of growing production of ethanol from biomass, its valorization into higher value chemicals such as ethylene, 1,3butadiene and $n$-butanol has attracted much attention recently. ${ }^{[1]}$ Besides being an important industrial chemical for paints and polymers, as well as a solvent, ${ }^{[2]} n$-butanol is also considered as a potential gasoline fuel additive ${ }^{[1 a, 3]}$ due to its higher energy density and its lower miscibility in water relative to ethanol. ${ }^{[4]}$ Butanol is commonly produced via the hydroformylation reaction (oxo process) followed by a hydrogenation step. Yet these processes require fuel-derived feedstocks and severe operating conditions leading to high operating costs. ${ }^{[5]}$ Recently, it was shown that $n$-butanol can be alternatively produced via the coupling of ethanol molecules over a wide variety of catalysts, ${ }^{\text {[3a, }}$ ${ }^{6]}$ among which the hydroxyapatite (HAps) system appeared to be very attractive due to its high activity and selectivity. ${ }^{[4,6 a, 7]}$

[a] Manel Ben Osman, Jean-Marc Krafft, Cyril Thomas, Guylène Costentin Laboratoire Réactivité de Surface, LRS, Sorbonne Université, CNRS 75005 Paris, France.

guylene.costentin@upmc.fr

[b] Tetsuya Yoshioka, Jun Kubo

Central Research Center, Sangi Co., Ltd.

Fudoinno 2745-1, Kasukabe-shi, Saitama 344-0001, Japan

Supporting information for this article is given via a link at the end of the document

Although still debated in the literature, it is commonly reported that the ethanol coupling to $n$-butanol occurs via a Guerbet-type mechanism. ${ }^{[7 a, 7 b, 7 d]}$. In the related Guerbet transformation, ${ }^{[8]}$ an ethanol molecule is firstly dehydrogenated into acetaldehyde. Acetaldehyde then reacts via an aldol condensation reaction to form unsaturated condensation products that are eventually hydrogenated to $n$-butanol, ${ }^{[9]}$ possibly via a Meerwein-PonndorfVerley-like mechanism. ${ }^{[10]}$ This pathway is supported by recent kinetic studies, ${ }^{[4]}$ in which adsorbed acetaldehyde species have been revealed as intermediates. Combining thermodynamic and kinetic data, Scalbert et al. concluded that $n$-butanol is both a primary product resulting from a "direct" bimolecular route (minor fraction) and a secondary product. ${ }^{[7 c]}$ Such a "direct" bimolecular route was also claimed for the $\mathrm{K}-\mathrm{Cu} / \mathrm{MgCeO}_{\mathrm{x}}$ system. ${ }^{[11]}$ According to Scalbert et al., the main "indirect" route to $n$-butanol would result from the condensation of acetaldehyde and ethanol, rather than from the self-condensation of acetaldehyde. ${ }^{[7]}$ Further insights into the understanding of the mechanism of formation of $n$-butanol from ethanol would require the identification of the nature of the active sites involved in the transformation of ethanol to $n$-butanol of the hydroxyapatite system. To date, it is assumed that the Guerbet coupling reaction requires weak acid-base bifunctional catalysts with a "proper balance of acid-base site pairs", that might explain the better catalytic performance of HAps compared to $\mathrm{MgO}^{[4 a]}$. Finally, it was reported recently that the active sites involved in the formation of acetaldehyde and $n$-butanol are different. ${ }^{[\mathrm{b}]}$

Hydroxyapatite $\left(\mathrm{Ca}_{10}\left(\mathrm{PO}_{4}\right)_{6}(\mathrm{OH})_{2}\right.$ generic formula) is a wellknown calcium phosphate compound that is also the main mineral component of bones and teeth. This biocompatible, ecofriendly and harmless material was recently found of interest in heterogeneous bifunctional ${ }^{[12]}$ and acid-base catalysis, ${ }^{[7 a,}$ 13] thanks to its synthesis-dependent tunable properties. ${ }^{[14]}$ It was found that changes in the $\mathrm{Ca} / \mathrm{P}$ bulk ratio influence the surface reactivity to a significant extent. ${ }^{[14 a, 15]} \mathrm{Ca} / \mathrm{P}$ ratios lower than the stoichiometric ratio, i.e. 1.67, would favor acidity, while higher $\mathrm{Ca} / \mathrm{P}$ ratios would rather promote basicity. ${ }^{[7 a, 16]}$ Note, however, that the acid-base properties of HAps do not always follow the above-mentioned guidelines based on the $\mathrm{Ca} / \mathrm{P}$ ratio, especially when comparing hydroxyapatite samples prepared under different conditions. ${ }^{[14 \mathrm{~b}]}$ It must be stressed that the $\mathrm{Ca} / \mathrm{P}$ ratio does not only depend on the calcium content of the sample but also on its phosphorus content as phosphates, which itself strongly depends on the presence of carbonates. In addition, the $\mathrm{Ca} / \mathrm{P}$ bulk ratio does not account for the $\mathrm{OH}$ concentration. The latter was shown to be influenced to a significant extent by the presence of structural defects, as illustrated by the more general formula of HAps: $\mathrm{Ca}_{10-x-\mathrm{B}}\left(\mathrm{PO}_{4}\right)_{6-x-\mathrm{B}}\left(\mathrm{HPO}_{4}\right)_{x}\left(\mathrm{CO}_{3}\right)_{\mathrm{A}+\mathrm{B}}(\mathrm{OH})_{2-\mathrm{x}-2 \mathrm{~A}-\mathrm{B} \text {, in }}$ which $A$ and $B$ are related to carbonates located on hydroxyl and 
phosphate structural sites, respectively. ${ }^{[17]}$ The concentration of $\mathrm{OH}$ groups was thus found to be a more relevant descriptor than the $\mathrm{Ca} / \mathrm{P}$ ratio to account for the basic reactivity of HAps. ${ }^{[14 b]}$ The discrimination between bulk and surface species remains complex and investigations aiming at characterizing the surface at a molecular level are needed to identify the nature of the surface sites likely involved in acid-base catalysis. Bulk hydroxyl $(\mathrm{OH})$ and hydrogenophosphate $(\mathrm{POH})$ species could be discriminated recently from their surface species by FTIR and NMR using isotopic labelling. ${ }^{[18]}$ The infra-red fingerprints and relative thermal stabilities of $A$ - and $B$-type bulk and surface carbonates have also been reported. ${ }^{[17]}$ From the latter IR study, it was found that surface carbonates and hydrogenocarbonates are formed upon $\mathrm{CO}_{2}$ adsorption, which reveals the presence of potential Lewis basic sites such as $\mathrm{PO}_{4}$ and $\mathrm{OH}$ groups emerging from the channels running along the $c$-axis. ${ }^{[17]}$ However, when Brønsted basicity is involved, (ability to interact with a proton donor molecule such as acetylene), ${ }^{[17]}$ an acid-base pair is required. ${ }^{[19]}$ In such a case, only the $\mathrm{OH}$ groups were found to be involved in the adsorption processes. This can be explained by the fact that surface phosphate groups from phosphate-rich terminations $^{[20]}$ are protonated to $\mathrm{POH}$ groups to ensure the surface charge balance. ${ }^{[21]}$ Such a conclusion is supported by an earlier study in which Brønsted acidity was revealed by means of the adsorption of $\mathrm{CO}$, which is a basic probe molecule. ${ }^{[7] \mathrm{e}}$ These surface-terminating $\mathrm{POH}$ groups were found to be much more accessible than $\mathrm{Ca}^{2+}$ Lewis acid sites, whose limited surface concentration was further confirmed by complementary XPS and ISS measurements. ${ }^{[7 \mathrm{e}]}$ Consequently, the $\mathrm{POH}$ groups are likely involved as the acidic partners of the acid-base pairs interacting with a proton donor molecule, such as acetylene. ${ }^{[17]}$ Moreover, increasing the relative $\mathrm{POH}$ to calcium content of the top surface by modulation of the synthesis parameters was found to be beneficial to the basic reactivity of $\mathrm{HAps}^{[7 \mathrm{e}]}$ as measured by a model reaction such as the conversion of the 2-methyl-3-butyn-2ol $(\mathrm{MBOH}) .{ }^{[22]}$ Such an increase in the relative $\mathrm{POH}$ to calcium content of the top surface of HAps was also found to promote ethanol conversion and this was assigned to an appropriate acidbase balance. ${ }^{[7 e]} \mathrm{Ho}$ et al. suggested that $\mathrm{Ca}-\mathrm{O}$ and $\mathrm{CaO} / \mathrm{PO}_{4}{ }^{3-}$ pairs would be involved in the transformation of ethanol to $n$ butanol as active sites for the dehydrogenation and aldol condensation steps, respectively. ${ }^{[4 b]}$ Such a proposal remains uncertain when considering the structural properties of HAps, for which no evident $\mathrm{Ca}-\mathrm{O}-$ like species are present due to the facts that oxygen atoms in these materials belong to phosphate and hydroxyl groups, and the surface concentration in $\mathrm{Ca}^{2+}$ is limited. ${ }^{[7 e]}$ In contrast, the potential involvement of surface terminated acidic $\mathrm{POH}$ and basic $\mathrm{OH}$ groups has not been considered yet to our knowledge, even if it was recently reported that HAps are much more active and selective in $n$-butanol compared to other calcium phosphates. ${ }^{[23]}$

The operando DRIFT studies reported in the present article aim at investigating the nature and the role of the acidic and basic surface sites involved in the transformation of ethanol to $n$ butanol. For this purpose, hydroxyapatite samples with various
$\mathrm{Ca} / \mathrm{P}$ ratios are investigated and the influence of the activation temperature is also addressed for one particular sample. The modifications occurring on the related hydroxyapatite surfaces after their thermal activation are followed operando (reaction 1). In order to ascribe the perturbations of the surface vibrators to the catalytic active sites involved in the conversion of ethanol into acetaldehyde and $n$-butanol and/or to sites involved in deactivation processes, a further treatment under He flow was carried out at the reaction temperature before a second reaction step (reaction 2) was performed.

\section{Results and Discussion}

\section{Initial Surface states}

Absolute DRIFT spectra recorded at the end of the activation step are shown in figure 1. A corresponding representation of the related hydroxyapatite surface is reported in figure $\mathbf{2} \mathbf{A}$.

\subsection{Carbonation}

Figure 1 A shows that the HAp samples exhibit bulk A-type carbonates $\left(1414,1444\right.$ and $\left.1505 \mathrm{~cm}^{-1}\right)$ and few amounts of $B$ type carbonates, $\left(1456\right.$ and $\left.1545 \mathrm{~cm}^{-1}\right) \cdot{ }^{[17]}$ Due to their low thermal stability, surface carbonates formed on phosphate groups and expected at 1485 and $1385 \mathrm{~cm}^{-1[17]}$ vanish upon thermal pretreatment at 623 and $873 \mathrm{~K}$. An additional band is also observed at $1577 \mathrm{~cm}^{-1}$, which relative intensity decreases as the $\mathrm{Ca} / \mathrm{P}$ ratio decreases. This band, which is ascribed to the $v_{\mathrm{Oco}}$ vibrator of surface unidentate calcium carbonates, ${ }^{[24]}$ vanishes upon activation at $873 \mathrm{~K}$.

\subsection{Hydroxylation}

\subsubsection{Hydroxyls from the channels}

All of the HAp samples exhibit an intense absorption band at $3566 \mathrm{~cm}^{-1}$ (figure $1 \mathrm{~B}$ ). This band is attributed to the $\mathrm{V}_{\mathrm{OH}}$ vibrator of both bulk hydroxyl groups located in the channels running along the $c$-axis and to their top surface fraction. ${ }^{[18 a]}$ Compared to spectra recorded at $\mathrm{RT},{ }^{[18 \mathrm{a}]}$ the spectra recorded at $623 \mathrm{~K}$ reveal an additional $\mathrm{V}_{\mathrm{OH}}$ contribution at $3534 \mathrm{~cm}^{-1}$. The intensity of the band at $3566 \mathrm{~cm}^{-1}$ decreases whereas the intensity of the shoulder at $3534 \mathrm{~cm}^{-1}$ increases upon thermal activation at $623 \mathrm{~K}$ (not shown). As shown in figure $\mathbf{1} \mathbf{B}$ (green and red spectra), such a tendency is found to be promoted by activation at $873 \mathrm{~K}$. The band at $3534 \mathrm{~cm}^{-1}$ results from a dehydroxylation process in the channels, associated to thermally activated proton migration. ${ }^{[25]}$ This process leads to the formation of few $\mathrm{O}^{2-}$ ions inside the columns. Hence, as supported by analogy with earlier studies performed on fluorinated HAps, ${ }^{[26]}$ the band at $3534 \mathrm{~cm}^{-1}$ is assigned to $\mathrm{V}_{\mathrm{OH}}$ vibrators $\mathrm{H}$-bonded to the generated $\mathrm{O}^{2}$ species. It indirectly indicates the presence of $\mathrm{O}^{2-}$ species in the hydroxyapatite channels, mostly as bulk species, but also possibly as surface species emerging from the channels, as shown below. 

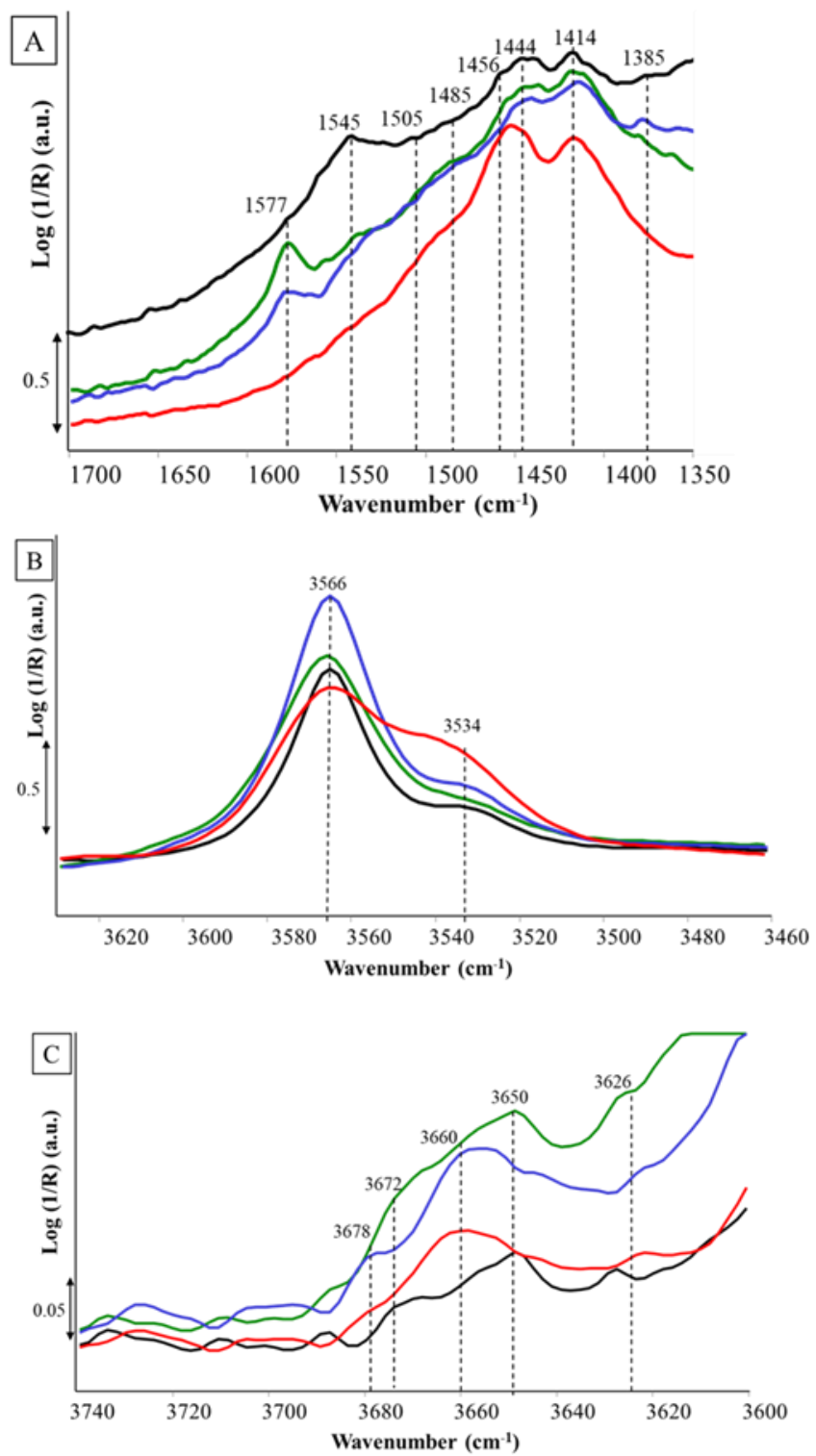

Figure 1. Absolute DRIFT spectra of $\mathrm{HAp}-\mathrm{S}_{623} \mathrm{~K}$ (blue), $\mathrm{HAp}-\mathrm{U}_{623} \mathrm{~K}$ (black), $\mathrm{HAp}-\mathrm{O}_{623} \mathrm{~K}$ (green) and $\mathrm{HAp}-\mathrm{O}_{873} \mathrm{~K}$ (red) recorded at $623 \mathrm{~K}$ at the end of the activation step in the A) $\mathrm{v}_{\mathrm{CO}}, \mathrm{B}$ ) $\mathrm{v}_{\mathrm{OH}}$ and $\mathrm{C}$ ) $\mathrm{v}_{\mathrm{PO}-\mathrm{H}}$ regions.

\subsubsection{Terminated $\mathrm{POH}$ groups}

Besides the bands associated to the $\mathrm{OH}$ groups from the channels, other low intensity $\mathrm{V}_{\mathrm{OH}}$ bands are detected at higher wavenumbers (figure 1 C). The bands at $3678,3672,3660$ and $3626 \mathrm{~cm}^{-1}$ are associated to terminating protonated phosphate groups located on the surface, whereas that at $3650 \mathrm{~cm}^{-1}$ originates from defective hydrogenophosphate groups present in the bulk. ${ }^{[14 b, 18 a]}$ The slight modifications of the shape of the spectra in this region are significant of different relative intensities for the various contributions. The origin of such a multiplicity of surface $\mathrm{POH}$ contributions is probably due to the presence of

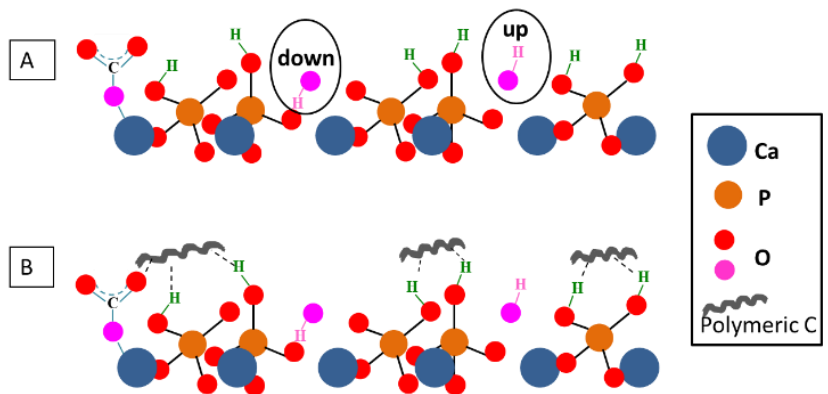

phosphate rich terminations with slightly different relaxation processes, and possibly to different protonation level of these phosphates.

Figure 2. Schematic representation of the terminated surface of HAps (A) freshly activated surface with up and down orientation for the protons of the basic $\mathrm{OH}$ groups, protonation of phosphate groups and unidentate calcium carbonates and (B) modified surface upon poisoning of the $\mathrm{POH}$ and unidentate calcium carbonates groups by carbon polymeric species.

\section{Reaction 1 step}

\subsection{Gas phase analysis}

It was shown earlier that catalytic performance measured in the DRIFT cell reactor was representative of that measured in a conventional reactor for similar contact times, ${ }^{[7]}$ eventhough lower conversions may be achieved compared to the conventional reactor probably due to differences in reactor geometry. Ethanol conversion decreases drastically for all of the samples within the 5 first minutes on stream (figure $3 \mathbf{A}$ ) and then much more slowly. Among the samples activated at $623 \mathrm{~K}$, the stoichiometric HAp-S $623 \mathrm{~K}$ and over-stoichiometric $\mathrm{HAp}-\mathrm{O}_{623 \mathrm{~K}}$

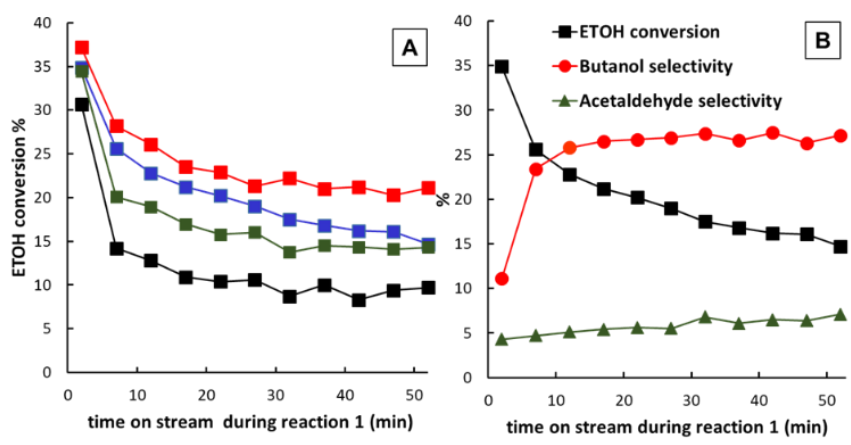

samples exhibit similar initial ethanol conversion (after 2 min on stream), whereas the under-stoichiometric $\mathrm{HAp}-\mathrm{U}_{623} \mathrm{k}$ sample appears to be less active. This ranking is maintained after $50 \mathrm{~min}$ on stream. Overall, after activation at $623 \mathrm{~K}, \mathrm{HAp}-\mathrm{S}_{623 \mathrm{~K}}$ seems to be the most active sample in agreement with earlier studies. ${ }^{[7 a]}$ This ranking (same than that obtained with U-type conventional reactor) is fully consistent with the ranking obtained for the basic reactivity evaluated by means of the $\mathrm{MBOH}$ model reaction ${ }^{[22]}$ (ESI 1 figure S1a). The present study therefore provides an additional support for a correlation already evidenced between the $\mathrm{MBOH}$ and ethanol conversions, as reported earlier. ${ }^{[7 \mathrm{e}]}$ In these earlier studies, it was proposed that similar acid-base pairs were involved in the rate determining step of the two reactions, ${ }^{[7 \mathrm{e}}$ which is likely to be the aldol condensation in the case of the ethanol condensation reaction. ${ }^{[\mathrm{b}, 7 \mathrm{~b}]}$ As already reported for HAps samples ${ }^{[4,6 a, 7 c-e]}$ and for the present samples tested in a $U$ type conventional reactor, ${ }^{[7 \mathrm{e}]}$ figure $\mathbf{3} \mathbf{B}$ shows that, beside acetaldehyde, which selectivity remains quite low ( 7\%), and very few amount of ethylene, the main reaction product is found to be $n$-butanol. Its production results from a quite complex reaction network including sequential steps that also lead to the formation of various products: other $\mathrm{C}_{4-}$ compounds such as 3 butene-2-ol, 3-butene-1-ol, 2-methyl-2-propene-1-ol, 1,3butadiene and diethylether and $\mathrm{C}_{6}{ }^{-}$compounds (2-ethylbutanol and hexanol). 
Figure 3. Reaction 1 step: (A) Evolution of the ethanol conversion upon time on stream for $\mathrm{HAp}-\mathrm{S}_{623 \mathrm{~K}}$ (blue), $\mathrm{HAp}-\mathrm{U}_{623 \mathrm{~K}}$ (black), $\mathrm{HAp}-\mathrm{O}_{623 \mathrm{~K}}$ (green) and $\mathrm{HAp}-\mathrm{O}_{873 \mathrm{~K}}(\mathrm{red}),(\mathrm{B})$ evolution of the ethanol conversion and the selectivity in the main detected products upon time on stream for the HAp-S $S_{623} \mathrm{k}$ sample.

As illustrated for HAp-S $\mathrm{S}_{623 \mathrm{~K}}, n$-butanol selectivity rapidly increases within the 5 first minutes on stream (figure $\mathbf{3}$ B) and then stabilizes around $25 \%$. The lower $n$-butanol selectivity compared to the earlier studies perfomed in a conventional reactor ${ }^{[7 \mathrm{e}]}(\sim 50$ $60 \%$ depending on the HAps stoichiometry) may be attributed to the low flow rate that had to be used in the present study due to the limited amount of sample introduced in the DRIFT cell. Such operating conditions were shown to favor secondary reactions. ${ }^{[4 a]}$ Here, they even hinder the desorption of heavy products being responsible of the decrease of $n$-butanol and other heavy products evolved in gas phase, and hence accounting for the gas-phase carbon deficit observed in the present operando experiments. Due both to these phenomena and to the different EtOH conversion levels measured for the different HAps samples (figure 3A), the different selectivities in $\mathrm{C}_{4^{-}}$- compounds obtained for HAps of various stoichiometries is rather difficult to comment. Despite a lower surface area, $\mathrm{HAp}-\mathrm{O}_{873} \mathrm{k}$ is the most active sample with the greatest $n$-butanol yield and the least sensitive to deactivation (figure $3 \mathbf{A}$ ). Such a positive effect of the high activation temperature has not been reported to date in the transformation of ethanol to our knowledge. Similar trends were also obtained for HAp-S and when characterizing these samples by means of the MBOH model reaction (ESI 1 figure S1a). Given that $\mathrm{MBOH}$ conversion on HAps was shown to be dependent on the $\mathrm{OH}^{-}$concentration ${ }^{[14 \mathrm{~b}]}$ and that the increase of the activation temperature favors dehydroxylation leading to the formation of $\mathrm{O}^{2-}$ species (figure $2 \mathrm{~B}$ ), these results raise the question of the role of $\mathrm{OH}^{-}$versus $\mathrm{O}^{2-}$ in the catalytic transformation of ethanol to $n$-butanol. Ho et al. have only considered $\mathrm{O}^{2-}$ species as active sites, ${ }^{[4 b]}$ thus neglecting the eventual involvement of $\mathrm{OH}^{-}$species. Note also that in the case of the cobalt aor vanadium hydroxyapatite system, specific active species derived from $\mathrm{OH}^{-}$ groups were proposed to favor the activation of the $\mathrm{C}-\mathrm{H}$ bonds of propane. ${ }^{[27]}$

\subsection{Surface analysis by DRIFT}

The difference DRIFT spectra exhibit positive and negative contributions ascribed to the formation of newly adsorbed species and to the perturbation and/or the disappearance of preexisting bands, respectively, as detailed below for the HAp-S $\mathrm{S}_{623 \mathrm{~K}}$. The assignments of the related IR bands are summarized in Table 1.

\subsubsection{Newly adsorbed species}

Figure 4 A shows the rather rapid appearance of several contributions at 2963, 2930, 2880 and $2862 \mathrm{~cm}^{-1}$ under time on stream. These contributions are assigned to the vibrations of $\mathrm{C}-\mathrm{H}$ groups originating from adsorbed reactant and/or products. ${ }^{[28]} \mathrm{C}$ O contributions of low intensity are observed at $1390-1470 \mathrm{~cm}^{-1}$ together with an intense multicomponent bands around 1500-
$1670 \mathrm{~cm}^{-1}$ gathering two main $v_{\mathrm{co}}$ contributions at 1554 and 1536 $\mathrm{cm}^{-1}$ and a less intense $v_{\mathrm{cc}}$ contribution at $1596 \mathrm{~cm}^{-1}$ (figure 4 B). These bands are assigned to carboxylates ${ }^{[28 c]}$ possibly in heavy polymeric compounds. ${ }^{[29]}$ The increasing formation of these adsorbates contribute to the gas-phase carbon deficit (figure $3 \mathbf{B}$ ) and to the deactivation process, as shown by the correlation between the evolution of the area of the 1500-1650 $\mathrm{cm}^{-1}$ contributions and the loss of ethanol conversion upon time on stream (figure 5). The strong adsorption of polymeric compounds is also supported by the yellow-brownish color observed for the used catalysts. Note that there is no evidence for the formation of chemisorbed water (band expected $~ 1640$ $\mathrm{cm}^{-1}$ ). The absence of adsorbed acetaldehyde (bands expected at $\left.\left.1709-1711 \mathrm{~cm}^{-1}\right),{ }^{[28 a}, 28 \mathrm{~b}\right]$ is indicative that acetaldehyde is rapidly desorbed or transformed.
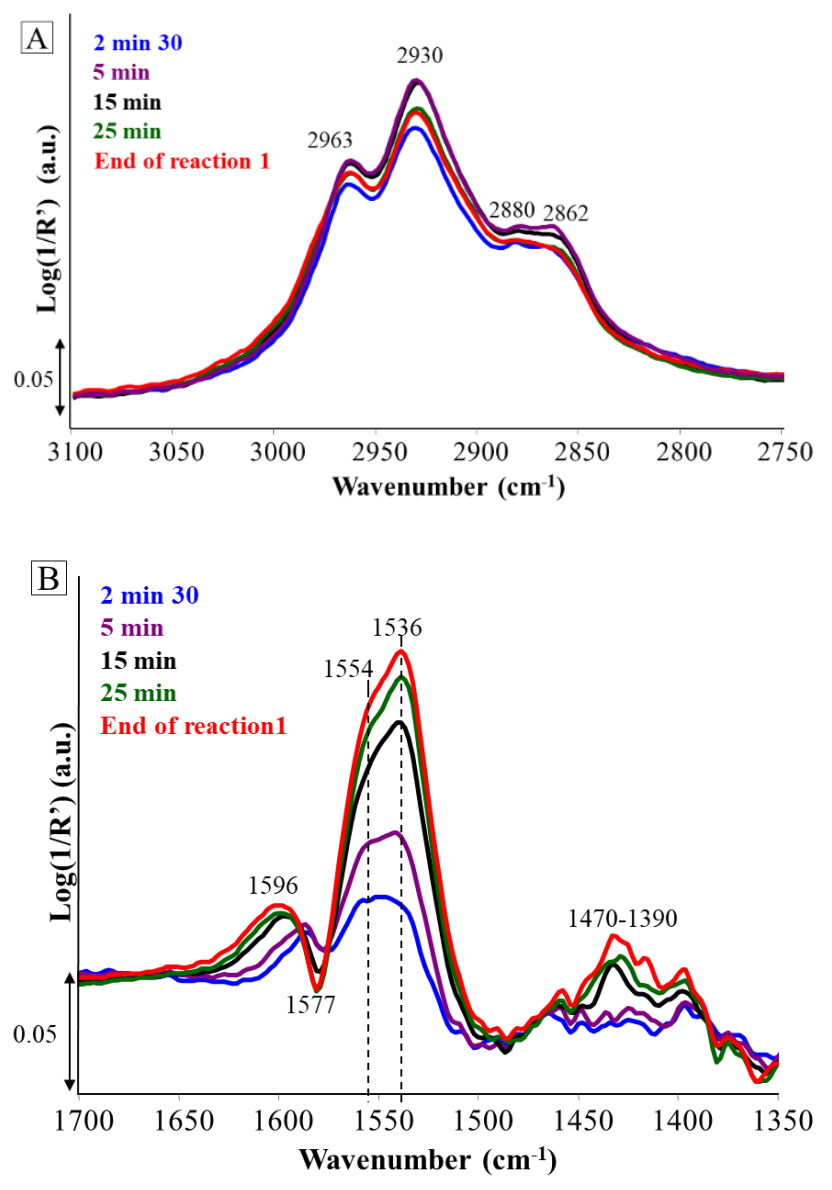


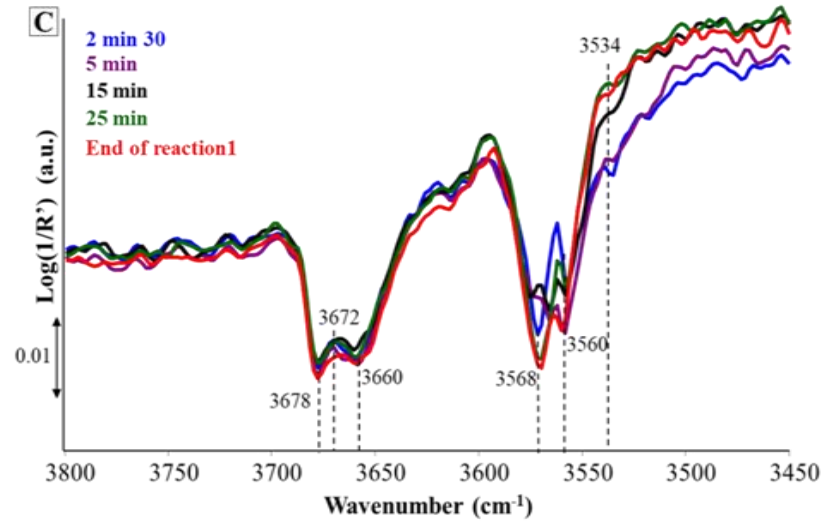

Figure 4. Difference DRIFT spectra recorded during reaction 1 for the HAp-S $\mathrm{S}_{623 \mathrm{~K}}$ sample. A) $v_{\mathrm{CH}}$, B) $v_{\mathrm{CO}}$ and $v_{\mathrm{CC}}$ and C) $v_{\mathrm{OH}}$ regions.

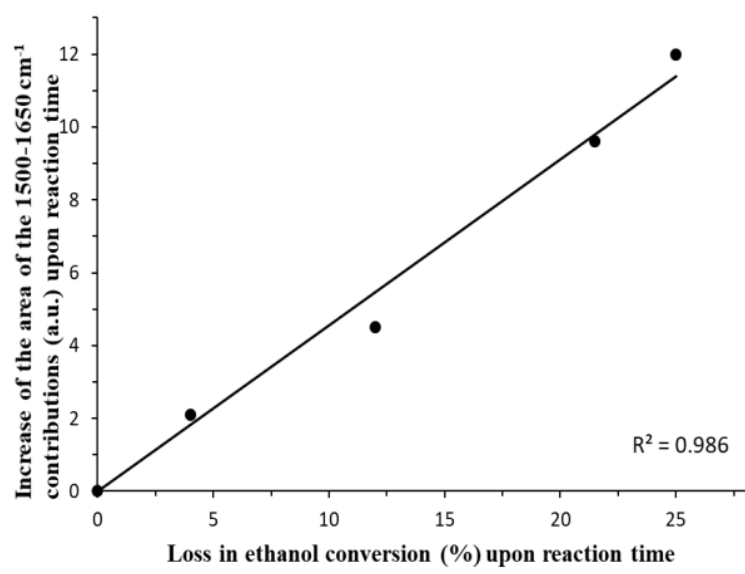

Figure 5. Correlation between the loss in ethanol conversion and the increase of the area of the contribution in the $1500-1650 \mathrm{~cm}^{-1}$ range for the HAp-S $\mathrm{S}_{623 \mathrm{~K}}$ sample.

Table 1. Assignment of the IR bands related to vibrators originating from hydroxyapatite sites and adsorbates

\begin{tabular}{llccc}
\hline Species & Location & vibrator & $\begin{array}{c}\text { Wavenumber } \\
\left(\mathrm{cm}^{-1}\right)\end{array}$ & Reference \\
\hline Bulk type A & $v_{\mathrm{CO}}$ & $\begin{array}{c}1414 \\
1444 \\
1505\end{array}$ & {$[17]$} \\
& & 1456 \\
\cline { 2 - 4 } & & $v_{\mathrm{CO}}$ & 1545
\end{tabular}

\begin{tabular}{|c|c|c|c|c|}
\hline \multirow{3}{*}{ Carbonates } & \\
\hline & $\begin{array}{l}\text { Surface } \\
\text { (in interaction with } \\
\mathrm{PO}_{4}{ }^{3-} \text { ) }\end{array}$ & $v_{\mathrm{CO}}$ & $\begin{array}{l}1485 \\
1385\end{array}$ & \\
\hline & $\begin{array}{l}\text { Unidentate calcium } \\
\text { carbonates }\end{array}$ & voco & 1577 & [24] \\
\hline
\end{tabular}

Bulk and surface $\quad v_{\mathrm{O}-\mathrm{H}} \quad 3566$

3566

$\mathrm{OH}$ of the columns

\begin{tabular}{|c|c|c|c|c|}
\hline \multirow[t]{2}{*}{ Hydroxyls } & $\begin{array}{l}\text { Columnar } \mathrm{OH}^{-} \text {in } \mathrm{H}- \\
\text { bonding interaction } \\
\text { with neighboring } \\
\text { columnar } \mathrm{O}^{2-} \text { (bulk } \\
\text { and surface) }\end{array}$ & $v_{\mathrm{O}-\mathrm{H}}$ & 3534 & [26] [a\} \\
\hline & $\begin{array}{l}\text { Splitted into } 2 \\
\text { surface } \mathrm{OH} \\
\text { contributions } \\
\text { revealed upon } \\
\text { interaction of } \\
\mathrm{C}_{2} \mathrm{H}_{5} \mathrm{OH} \text { with the } \\
\text { surface }\end{array}$ & $v_{\mathrm{O}-\mathrm{H}}$ & $\begin{array}{l}3568 \\
3560\end{array}$ & [17] \\
\hline \multirow[t]{2}{*}{$\begin{array}{l}\text { Protonated } \\
\text { Phosphates }\end{array}$} & $\begin{array}{c}\text { Terminal surface } \\
\mathrm{POH}\end{array}$ & VPO-H & $\begin{array}{l}3678 \\
3672 \\
3660 \\
3626 \\
\end{array}$ & {$[14 b, 18 a]$} \\
\hline & Bulk $\mathrm{POH}$ & VPO-H & 3650 & [18a] \\
\hline $\begin{array}{l}\text { Ethanol and } \\
\text { Products }\end{array}$ & $\begin{array}{c}\text { Adsorbed on the } \\
\text { surface }\end{array}$ & $v_{C-H}$ & $\begin{array}{l}2963 \\
2930 \\
2880 \\
2862 \\
\end{array}$ & {$[28 \mathrm{a}, 28 \mathrm{c}]$} \\
\hline $\begin{array}{l}\text { Carboxylates } \\
\text { /heavy } \\
\text { Polymeric } \\
\text { compounds }\end{array}$ & $\begin{array}{c}\text { Adsorbed on the } \\
\text { surface }\end{array}$ & $\begin{array}{c}v_{\mathrm{sCOO}} \\
v_{\mathrm{asOCO}} \\
v_{\mathrm{C}-\mathrm{C}}\end{array}$ & $\begin{array}{c}1390-1470 \\
1536,1554 \\
1596\end{array}$ & $\begin{array}{l}{[28 \mathrm{c}]} \\
{[28 \mathrm{c}]} \\
{[29]}\end{array}$ \\
\hline
\end{tabular}

[a] by analogy with $v_{\mathrm{O}-\mathrm{H}}$ at $3546 \mathrm{~cm}^{-1}$ in hydroxyapatites modified by fluoride assigned to an $\mathrm{OH}^{-}--\mathrm{F}^{-}$contribution.

\subsubsection{Perturbation of pre-existing surface species}

The band at $1577 \mathrm{~cm}^{-1}$ is perturbed from the first minutes on stream of the reaction 1 step (figure $4 \mathbf{B}$ ). The increase in intensity of this perturbation with time on stream is in line with the involvement of an interaction of the related unidentate calcium carbonate species with adsorbates, rather than with their sudden vanishing under reactant flow.

The surface contribution of hydroxyl groups emerging from the channels is also modified (figure $4 \mathrm{C}$ ). The band at $3534 \mathrm{~cm}^{-1}$, which appears after the thermal activation process (figure $\mathbf{1} \mathbf{B}$ ), is only slightly modified under reaction conditions. This is consistent with the main assignment of this contribution to $\mathrm{OH}$ groups $\mathrm{H}$-bonded to bulk $\mathrm{O}^{2-}$ species. This contribution also indicates the presence of a limited fraction of the $\mathrm{O}^{2-}$ species on the surface and of their involvement in the catalytic reaction, as discussed below. Whereas only one contribution at $3566 \mathrm{~cm}^{-1}$ could be identified from the absolute spectra of the thermallyactivated surface (including both bulk and surface species) (figure $1 \mathrm{~B}),{ }^{[18 \mathrm{a}]}$ the exposure of the HAp surface to ethanol and/or its products reveals two perturbed contributions at 3560 and $3568 \mathrm{~cm}^{-1}$ (figure $4 \mathrm{C}$ ). Such a splitting was also observed for the interaction of acetylene with the HAp surface ${ }^{[17]}$ and following the $\mathrm{MBOH}$ reaction under operando conditions (ESI 1

Figure S1b). Several explanations can account for such a surface $\mathrm{OH}$ differentiation (figure $3 \mathbf{A}$ ). Firstly, the existence of two different surface terminating hydroxyl groups with up and down orientations of the protons with respect to oxygen was recently evidenced in a NMR study. ${ }^{[18 b]}$ Such a speciation, which cannot be seen in the absolute IR spectrum due to the much 
higher concentration of bulk $\mathrm{OH}$ species compared to surface $\mathrm{OH}$ species, ${ }^{[18 a]}$ might be more easily observable in the difference spectra that are only sensitive to surface modifications. Such different up and down configurations might lead to slightly different basicity or accessibility and thus to slightly different reactivity. Secondly, in the context of basic reactivity, acid-base pairs are involved and one may also consider the involvement of basic $\mathrm{OH}^{-}$species with different acidic partners $\left(\mathrm{Ca}^{2+}\right.$ versus $\mathrm{POH}$, and/or different $\mathrm{POH}$ species as suggested by the various surface $\mathrm{V}_{\mathrm{PO}-\mathrm{H}}$ contributions pointed out in figure $\mathbf{1} \mathbf{C}$ and reported in table 1) with different strengths resulting in the differentiation of $\mathrm{OH}^{-}$species (figure $2 \mathrm{~A}$ ). Note that as reported earlier for identical materials, the accessibility of $\mathrm{Ca}^{2+}$ ions as potential Lewis acid sites was shown to be quite limited compared to that of $\mathrm{POH}$ from CO-FTIR adsorption measurements at $77 \mathrm{~K}^{\left[{ }^{[17]}\right.} \mathrm{In}$ the present study, this lack of accessibility may be explained by the presence of stable surface unidentate calcium carbonates. The negative contributions at 3678,3672 and $3660 \mathrm{~cm}^{-1}$ attributed to the perturbation of the surface $\mathrm{POH}$ vibrators (figure $4 \mathrm{C}$ ) clearly reveal their involvement in the reaction. Note that the intensity of these perturbations (quite similar for the three components) does not match that observed on the absolute spectra shown in figure $\mathbf{1} \mathbf{C}$ (the intensity of the bands increases in the order $3678<3672<33660 \mathrm{~cm}^{-1}$ ). Similar features were obtained using acetylene and $\mathrm{CO}$ probes and were ascribed to different $\mathrm{POH}$ acidic strengths, accessibility and/or proximity with the neighboring $\mathrm{OH}$ surface basic sites. ${ }^{[17]}$ Interestingly, similar features are also observed following the $\mathrm{MBOH}$ reaction under operando conditions (ESI 1 Figure S1b).
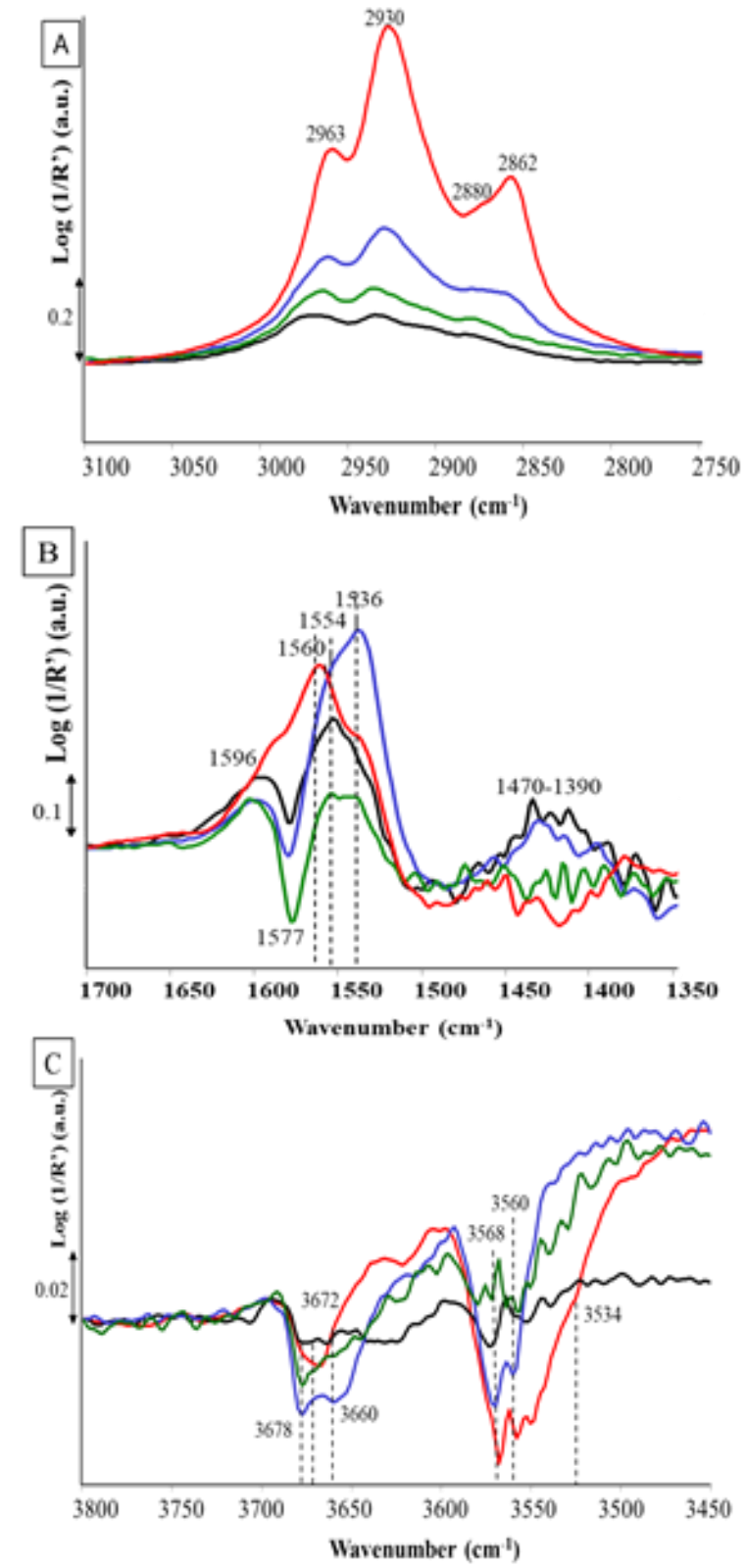

Figure 6. Difference DRIFT spectra recorded at the end of the reaction 1 step for the HAp-S $\mathrm{S}_{623 \mathrm{~K}}$ (blue), HAp- $\mathrm{U}_{623 \mathrm{~K}}$ (black), HAp-O $\mathrm{O}_{623 \mathrm{~K}}$ (green) and HAp-O $\mathrm{O}_{873 \mathrm{~K}}$ samples (red) in the (A) $v_{\mathrm{CH}}(\mathrm{B}) v_{\mathrm{CO}}$ and (C) $v_{\mathrm{OH}}$ regions.

\subsection{Comparison of the various HAp samples}

Overall, similar tendencies are observed for all of the HAp samples. This can be seen upon reaction time on stream in the case of the most active sample (HAp- $\mathrm{O}_{873} \mathrm{k}$ ) (ESI 2 Figure S2). Consequenty, only the spectra recorded at the end of the reaction 1 step are reported here for all of the samples. The changes in intensity of the positive $\mathrm{C}-\mathrm{H}$ contributions (figure $6 \mathrm{~A}$ ) on the difference spectra can account for the differences in conversion and deactivation profiles observed for the various samples (figure 3 A). The intensity of the negative contributions at 1577, $3678,3672 \mathrm{~cm}^{-1}$ are in line with the intensity of these bands on the absolute spectra recorded before reaction (figure 6 B, C versus figure $1 \mathrm{~A}, \mathbf{C}$ ). The contribution at $1500-1670 \mathrm{~cm}^{-1}$ (figure $6 \mathrm{~B})$ may be attributed to the presence of various types of carbon adsorbates. By comparing the samples with various 
stoichiometries activated at $623 \mathrm{~K}$, it is found that the higher the perturbation of the bands related to $\mathrm{OH}$ emerging from the channels is, the higher the $\mathrm{EtOH}$ conversion is. This behavior is also valid when considering the perturbation of the $\mathrm{POH}$ areas. However, the intensity of the perturbation of the whole $\mathrm{POH}$ area recorded during reaction 1 does not match the absolute intensities of the $\mathrm{POH}$ area recorded after activation step (see $\mathrm{HAp} \mathrm{O}_{623} \mathrm{k}$ versus HAp-S $\mathrm{S}_{623} \mathrm{k}$ in figure $1 \mathrm{C}$ ). Such a different behavior can be attributed to the fact that, as mentioned in the former section, the contribution at $3678 \mathrm{~cm}^{-1}$, particularly intense for HAp-S $S_{623} \mathrm{~K}$ is comparatively more perturbed than the $\mathrm{POH}$ contributions at lower wavenumbers. In the case of the $\mathrm{HAp}-\mathrm{O}_{873}$ к sample (ESI 2, figure S2), beside the absence of a negative signal at $1577 \mathrm{~cm}^{-1}$ that confirms the release of unidentate carbonates at high temperature (red spectrum in figure 6 B), the fraction of perturbed $\mathrm{OH}$ vibrators is not only much greater than that for $\mathrm{HAp}_{-} \mathrm{O}_{623} \mathrm{k}$ (comparison of green and red spectra in figure $6 \mathrm{C}$ ), but also the most intense among all of the investigated samples. This confirms the correlation between the intensity of the perturbation of the $\mathrm{OH}$ contributions and the $\mathrm{EtOH}$ conversion. In addition, for $\mathrm{HAp}-\mathrm{O}_{873} \mathrm{~K}$, a broadening of the negative signal is also observed with a perturbation of the contribution at $3534 \mathrm{~cm}^{-1}$ (indirectly related to the formation of $\mathrm{O}^{2-}$ species). This is in line with the relative increase of the $3534 \mathrm{~cm}^{-1}$ contribution compared to that at $3566 \mathrm{~cm}^{-1}$ observed upon increasing the temperature of the thermal pretreatment (see green and red spectra in figure $1 \mathrm{~B}$ ). This strongly suggests that, in addition to basic surface $\mathrm{OH}^{-}$groups, the corresponding fraction of surface $\mathrm{O}^{2-}$ species (expected to be more basic) are also involved in the catalytic process. This might also account for the higher reactivity of the sample activated at the higher temperature for the $\mathrm{MBOH}$ reaction (ESI 1 figure S1a).

\section{Evolution under He flow}

In order to evaluate the reversibility of the surface processes occurring during the reaction, ethanol was suddenly removed from the flow at $623 \mathrm{~K}$.

\subsection{Desorption of the products detected in gas phase}

As shown in the case of the HAp-S $S_{623} \mathrm{k}$ sample in figure 7, the amounts of acetaldehyde, $n$-butanol and ethanol detected in the gas phase progressively decrease. $n$-butanol is no longer observed after 35 min under He flow, whereas ethanol and acetaldehyde are still observed after $55 \mathrm{~min}$ on stream. Note also that few unidentified peaks, probably related to the desorption of some unidentified heavy products, were also detected.

\subsection{State of the HAp surfaces monitored by DRIFT} 3.2.1 Evolution of the adsorbates

For all of the HAp samples, the intensity of the contributions associated to $v_{\mathrm{C}-\mathrm{H}}\left(2800-3000 \mathrm{~cm}^{-1}\right)$ decreases under helium flow.

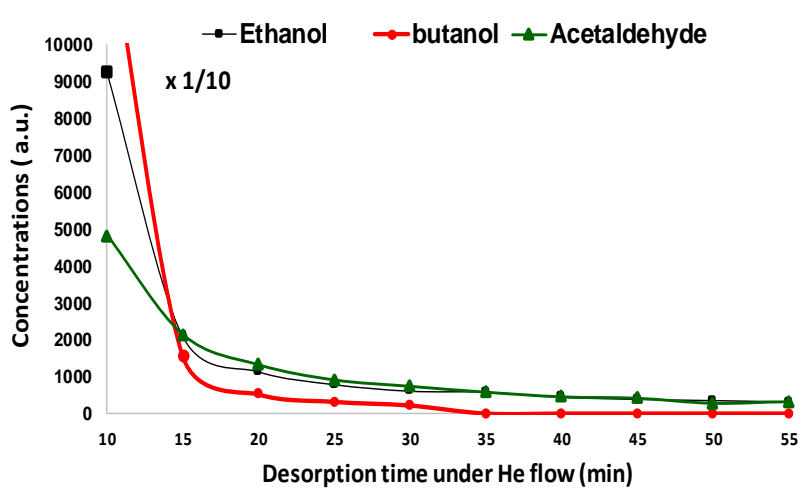

Figure 7. Evolution of the $\mathrm{EtOH}$ and the products concentrations in gas phase under helium flow for the HAp-S $\mathrm{S}_{623 \mathrm{~K}}$ sample.

After 2 hours under $\mathrm{He}$ flow, only about half of the $\mathrm{C}-\mathrm{H}$ adsorbates formed during reaction 1 were released (figure $8 \mathbf{A}$ ). In contrast, the intensity of the multi-components band at 1500 $1650 \mathrm{~cm}^{-1}$ increases slightly under helium flow (figure 8 B). This indicates that the corresponding carboxylates, which formation started during reaction $1 \mathrm{step}$, are strongly adsorbed. Moreover, even in the case of the HAp- $\mathrm{O}_{873} \mathrm{k}$ sample (ESI 2 figure S2) that is the only sample not exhibiting the characteristic band ascribed to unidentate calcium carbonates, a significant increase in the intensity of the $1596-1587 \mathrm{~cm}^{-1}$ signal assigned to $v_{\mathrm{CC}}$ vibrators is observed (figure 9 B), which indicates an increasing formation of carbon polymeric species under helium flow.

\subsubsection{Poisoning and Regeneration of the surface sites?}

For all of the samples, neither the unidentate calcium carbonates (when initially present) (figures 8 B, 9 B) nor the surface $\mathrm{POH}$ groups (figures $8 \mathrm{C}, \mathbf{9} \mathbf{C}$ ) are regenerated under He flow. Compared to the spectrum recorded at the end of the reaction 1 step, the $\mathrm{POH}$ vibrators are even slightly more perturbed over time under He flow (figure $8 \mathrm{C}$ ). Such a perturbation of the $\mathrm{POH}$ groups under He flow is indicative of their strong interaction with the adsorbates formed under the reaction 1 step. This also shows that all of the $\mathrm{POH}$ groups have not been fully poisoned during the reaction 1 step and therefore remained available for the reaction.

Regarding the $\mathrm{OH}$ region, the perturbation of the $\mathrm{OH}$ bands occurred during reaction 1 decreases upon time under He flow (figure $8 \mathrm{C}$ and figure $9 \mathrm{C}$ ), but at different extents depending on the samples. In particular, the HAp- $\mathrm{U}_{623} \mathrm{k}$ and $\mathrm{HAp}-\mathrm{O}_{623 \mathrm{~K}}$ samples do not show any neggative contributions around 357035A) End fof pratioblaseline on^the black and green difference spectra in 2 figure 9 C.p63 This 'suggests that the $\mathrm{OH}^{-}$groups previpusty present on the frefply activated samples have been fully regenerated under/ heli $\mathrm{m}$ ow? $28 \mathrm{Pence}$, contrary to surface PQH groups and Ipsssibly surface unidentate calcium cardonates, the surfade $\mathrm{OH}$ group must not directly be il olved in the formation of the farbon polymoric sppecies.

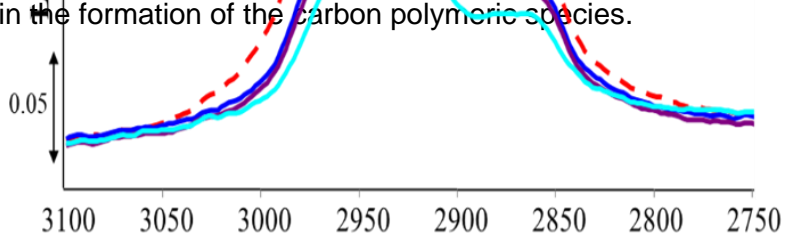

Wavenumber $\left(\mathrm{cm}^{-1}\right)$ 

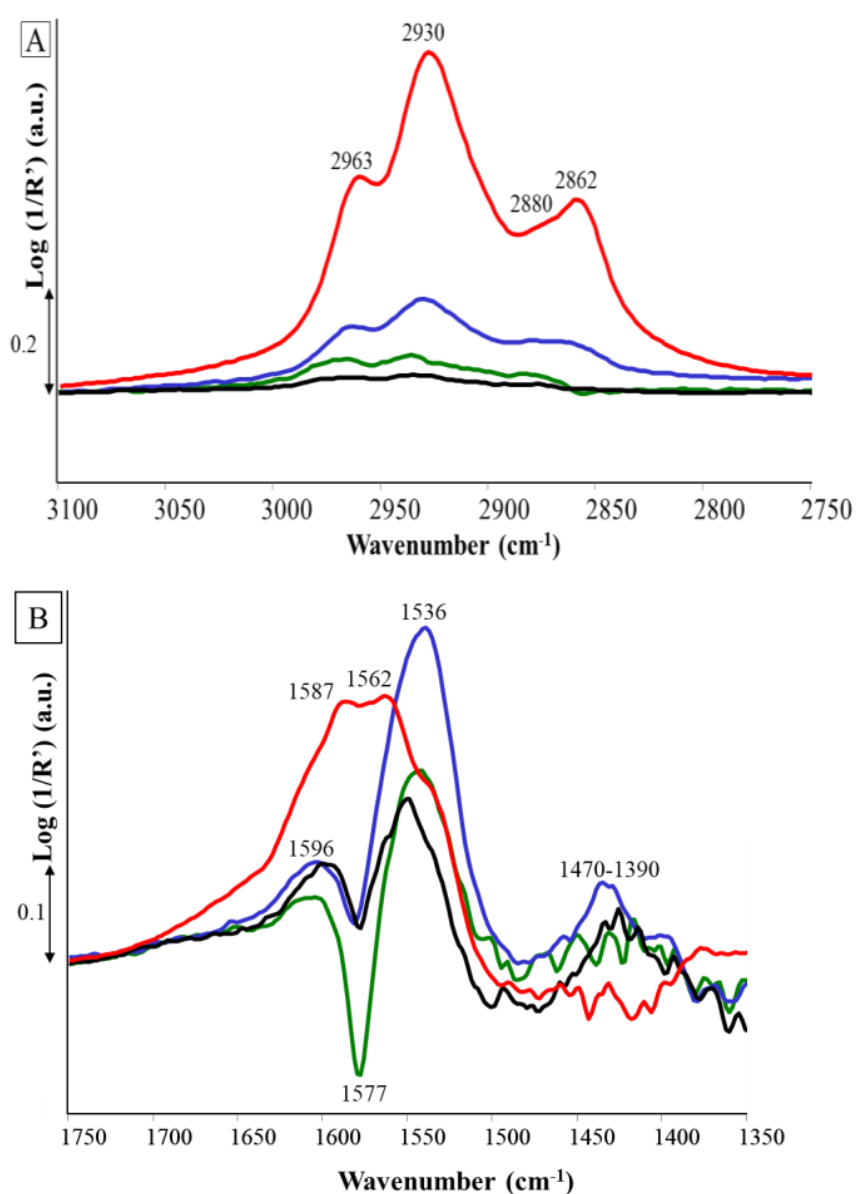

Figure 8. Difference DRIFT spectra recorded upon increasing exposure to $\mathrm{He}$ flow for the HAp-S $\mathrm{S}_{623 \mathrm{~K}}$ sample in the $(\mathrm{A}) v_{\mathrm{CH}}(\mathrm{B}) v_{\mathrm{CO}}$ and $(\mathrm{C}) v_{\mathrm{OH}}$ regions.

Moreover, the possible full regeneration of the $\mathrm{OH}^{-}$groups (figure $9 \mathrm{C}$ for $\mathrm{HAp}-\mathrm{U}_{623} \mathrm{k}$ and $\mathrm{HAp}-\mathrm{O}_{623} \mathrm{k}$ ) in the absence of ethanol in the feed may indicate their involvement in the interaction with ethanol. In contrast, only a limited fraction of the

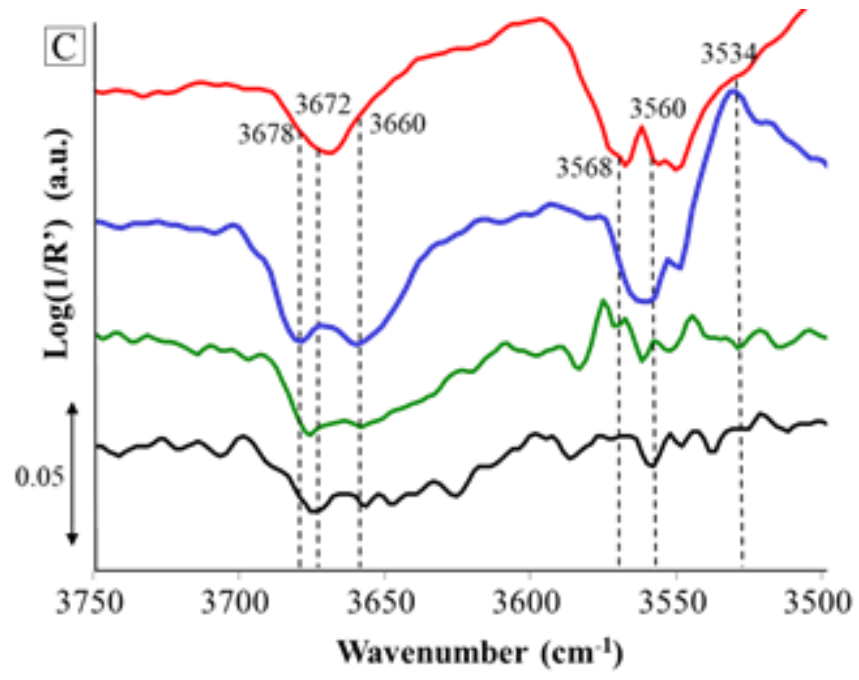

Figure 9. Difference DRIFT spectra recorded after 2 hours under He flow for HAp-S ${ }_{623 \mathrm{~K}}$ (blue), $\mathrm{HAp}-\mathrm{U}_{623 \mathrm{~K}}$ (black), HAp-O $\mathrm{O}_{623 \mathrm{~K}}$ (green) and $\mathrm{HAp}-\mathrm{O}_{873 \mathrm{~K}}$ (red) in the $(\mathrm{A}) v_{\mathrm{CH}}(\mathrm{B}) v_{\mathrm{CO}}$ and $(\mathrm{C}) v_{\mathrm{OH}}$ regions.

perturbed surface $\mathrm{OH}^{-}$groups at 3568 and $3560 \mathrm{~cm}^{-1}$ has been recovered under helium flow for $\mathrm{HAp}-\mathrm{S}_{623} \mathrm{k}$ and $\mathrm{HAp}-\mathrm{O}_{873} \mathrm{~K}$ samples (blue and red spectra in figure $6 \mathrm{C}$ and figure $9 \mathrm{C}$ ). This is also the case for the $3534 \mathrm{~cm}^{-1}$ contribution that is indirectly characteristic of the involvement of the $\mathrm{O}^{2-}$ species for

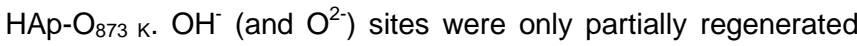
under $\mathrm{He}$ flow in the case of the most reactive samples toward $\mathrm{MBOH}\left(\mathrm{HAp}-\mathrm{O}_{873} \mathrm{k}\right.$ and $\left.\mathrm{HAp}-\mathrm{S}_{623} \mathrm{k}\right)$, but fully regenerated for the less active ones $\left(\mathrm{HAp}-\mathrm{O}_{623} \mathrm{k}\right.$ and $\left.\mathrm{HAp}-\mathrm{U}_{623} \mathrm{k}\right)$. The regeneration ability of surface $\mathrm{OH}^{-}$sites of these hydroxyapatite samples must 
therefore be correlated to the strength and/or density of the basic surface $\mathrm{OH}^{-}$groups evaluated by the conversion of $\mathrm{MBOH}$ into acetone and acetylene (ESI 1).

\section{Reaction 2 step}

The initial surface state associated with the reaction 2 step (end of He flow step) is different from that associated with reaction 1 step (end of activation step). As seen above, modifications on the related surfaces occurred between these two steps (figure 2). Unidentate calcium carbonates and $\mathrm{POH}$ groups are still present on the surface at the end of He flow step but no more accessible since they are now interacting strongly with adsorbed carbon polymeric species (figure $2 \mathrm{~B}$ ). Compared with the end of the activation step, basic $\mathrm{OH}$ - sites are present either in similar amounts (for HAp-U623 K and HAp-O623 K) or in lower amounts (for HAp-S623 K and HAp-O873 K). Let us examine how such modifications influence the surface reactivity.

\subsection{Gas phase analysis}

\subsubsection{Ability to recover the EtOH conversion}

As reported in figure $\mathbf{1 0}$, the ability of the samples to recover an initial conversion of ethanol during reaction 2 step comparable to that measured during the reaction 1 step is different from one sample to another. Ethanol conversion is fully recovered for HAp$\mathrm{U}_{623 \mathrm{~K}}$ and $\mathrm{HAp}-\mathrm{O}_{623 \mathrm{~K}}$, whereas a significant loss of conversion is observed for HAp-S $\mathrm{S}_{623} \mathrm{k}$ and $\mathrm{HAp}-\mathrm{O}_{873} \mathrm{k}$. Given that both $\mathrm{POH}$ groups and unidentate carbonates (when present for samples activated at $623 \mathrm{~K}$ ) are poisoned for all of the samples, none of these surface sites must be directly involved in the activation of ethanol. Interestingly, the fraction of ethanol conversion recovered during the reaction 2 step appears to be directly related to the fraction of surface $\mathrm{OH}^{-}$groups recovered upon the $\mathrm{He}$ step. Indeed, HAp- $\mathrm{U}_{623} \mathrm{k}$ and $\mathrm{HAp}-\mathrm{O}_{623} \mathrm{k}$ show a full regeneration of the surface $\mathrm{OH}^{-}$groups upon the He step (figure $9 \mathbf{C )}$ together with a full recovery of the initial ethanol conversion in reaction 2 step. In contrast, $\mathrm{HAp}-\mathrm{S}_{623 \mathrm{~K}}$ and $\mathrm{HAp}-\mathrm{O}_{873 \mathrm{~K}}$ show a partial regeneration of the $\mathrm{OH}^{-}$(and derived $\mathrm{O}^{2-}$ ) groups after the He step (figure $\mathbf{9} \mathbf{C}$ ) and a decrease in the initial ethanol conversion in reaction 2 step $(25 \%$ initial ethanol conversion in the reaction step 2 versus $35 \%$ in the reaction step 1 over HAp$\mathrm{S}_{623 \mathrm{~K}} \mathrm{k}$, figure 10). Hence, this shows that the conversion of ethanol on the HAp surface is clearly governed by the density and/or the strength of the surface basic $\mathrm{OH}^{-}$(and derived $\mathrm{O}^{2-}$ species) groups. Such an involvement of the $\mathrm{OH}^{-}$sites as active sites of the conversion of ethanol over HAp is also supported by the much lower activity and $n$-butanol selectivity obtained for other calcium phosphate phases that do not exhibit

basic $\mathrm{OH}^{-}$groups, such as beta tricalcium phosphate, fluroapatite ${ }^{[23]}$ and octacalcium phosphate ${ }^{[30]}$ that also exhibit poor basicity compared to HAps. ${ }^{[23,30]}$

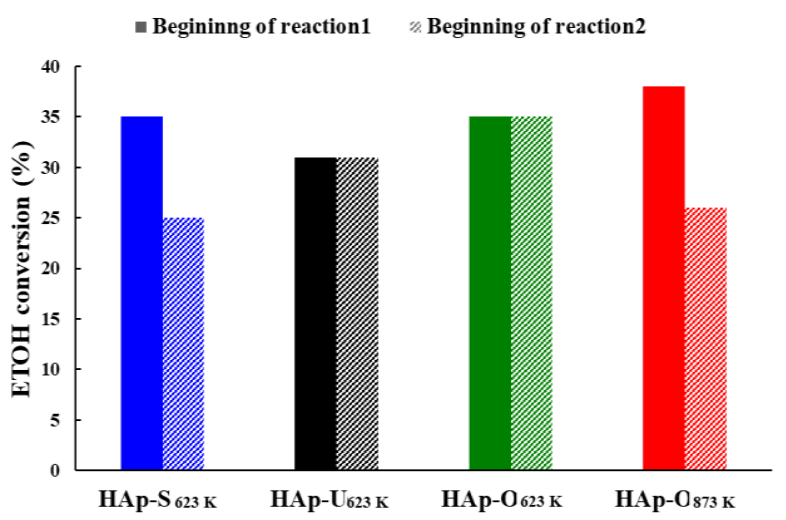

Figure 10. Comparison of the initial ethanol conversions between reaction 1 and reaction 2 steps for the HAp samples.

\subsubsection{Impact on the selectivity}

Regardless of whether the ethanol conversion has been fully recovered or not, the products selectivities in reaction 2 step were found to be greatly modified compared to reaction 1 step. For all of the samples, as illustrated for $\mathrm{HAp}-\mathrm{S}_{623 \mathrm{~K}}$ and $\mathrm{HAp}-\mathrm{U}_{623 \mathrm{~K}}$ in figure $11 \mathrm{~A}$ and $\mathbf{B}$, the production of $n$-butanol and acetaldehyde in the reaction 2 step are greatly modified.
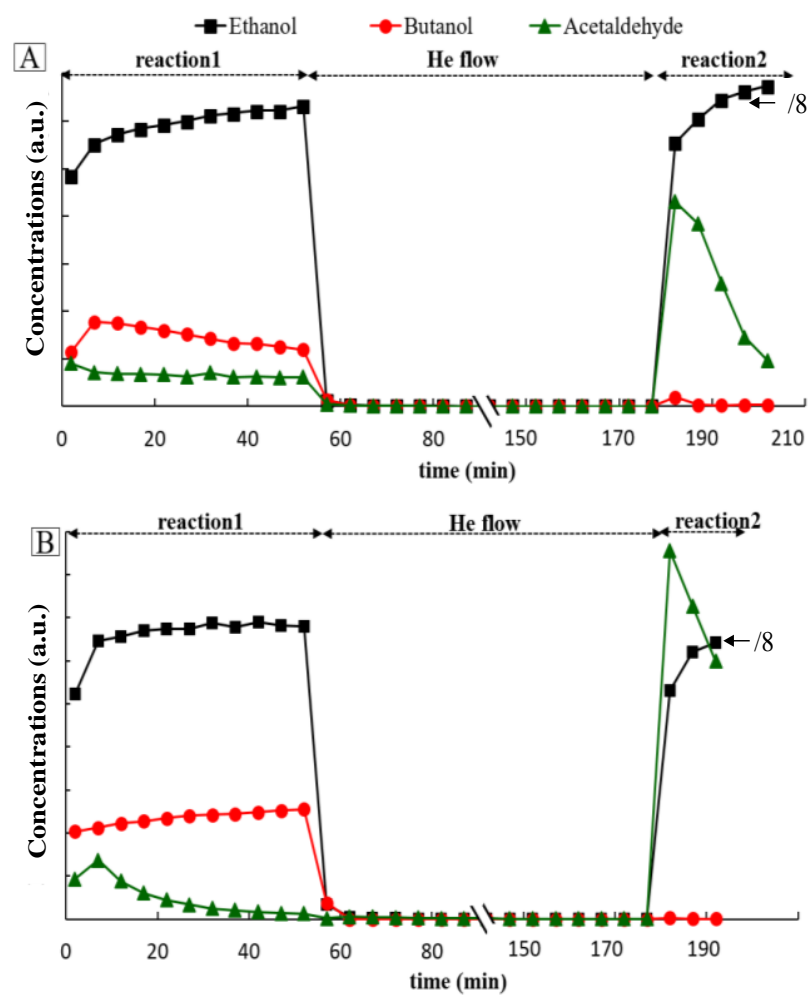

Figure 11. Evolution of the concentrations in ethanol, $n$-butanol and

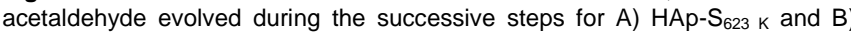
HAp- $U_{623} \mathrm{~K}$ samples. 
From the beginning of reaction 2 step, $n$-butanol is hardly produced, while the production of acetaldehyde is drastically increased compared to reaction 1 step. Such a sharp increase in acetaldehyde production during reaction 2 step is the most pronounced for $\mathrm{HAp}-\mathrm{U}_{623} \mathrm{k}$ by about a two-fold increase compared to other samples (figure $11 \mathrm{~B}$ ). In parallel, hydrogen concentration remained quite limited during reaction 1 step, as expected from its production upon the dehydrogenation step of ethanol to acetaldehyde, whereas a sharp increase in its concentration was observed during reaction 2 step (not shown).

\subsection{Nature of the acidic sites involved in the key reactions steps}

Such changes in the selectivity profiles between reaction steps 1 and 2 indicate that different active sites must be involved in the relevant key reaction steps, i.e. dehydrogenation for acetaldehyde formation and subsequent aldol condensation for $n$-butanol formation. Such a conclusion is in accordance with that already drawn by Ho et al. ${ }^{[4 b]}$

On HAp-S $S_{623} \mathrm{~K}$, the intensity of $v_{\mathrm{CH}}$ contributions (figure $12 \mathrm{~A}$ ) increases during the reaction 2 step and remains of lower intensity compared to those achieved at the end of the reaction 1 step. This lower concentration of adsorbed products is consistent with the lower ethanol conversion recorded during reaction 2 step compared to reaction 1 step (figures $\mathbf{1 0}$ and $\mathbf{1 1} \mathbf{A}$ ). In contrast, contributions associated to the presence of carbon polymeric species (1500-1650 $\mathrm{cm}^{-1}$ ) (figure 12 B) increase continuously. The perturbed bands related to $\mathrm{POH}$ sites are not modified upon the introduction of ethanol during the reaction 2 step (figure 12 C). This confirms that the $\mathrm{POH}$ groups have already been fully poisoned during the He step, as mentioned in the previous section. Hence, in the absence of regeneration of the surface $\mathrm{POH}$ acid sites (not recovered under He flow), it is likely that the few $\mathrm{Ca}^{2+}$ cations accessible on the surface still contribute to the reaction together with the regenerated surface basic $\mathrm{OH}^{-}$groups, as illustrated by the perturbation observed at $~ 3568 \mathrm{~cm}^{-1}$ in figure $12 \mathrm{C}$, finally promoting the formation of acetaldehyde. Whereas two negative contributions of similar intensity were observed at 3568 and $3560 \mathrm{~cm}^{-1}$ at the end of reaction 1 step (figure $4 \mathrm{C}$ ), figure $12 \mathrm{C}$ shows that the band at $3568 \mathrm{~cm}^{-1}$ is much more intense than that at $3560 \mathrm{~cm}^{-1}$ in reaction 2 step. Even if DFT calculations would be required to assess the origin of these two surface $\mathrm{OH}^{-}$contributions, this result may be an indication that the $3568 \mathrm{~cm}^{-1}$ contribution is characteristic of surface basic $\mathrm{OH}^{-}$groups acting cooperatively with $\mathrm{Ca}^{2+}$ ions as an acidic partner (whereas that at $3560 \mathrm{~cm}^{-1}$ may correspond to $\mathrm{OH}^{-}$groups acting together with $\mathrm{POH}$ groups).

Such a trend is also observed for the other samples (figure 13) (ESI 2), except for $\mathrm{HAp}-\mathrm{U}_{623 \mathrm{~K}}$ (see black spectra in figure $13 \mathrm{~B}$
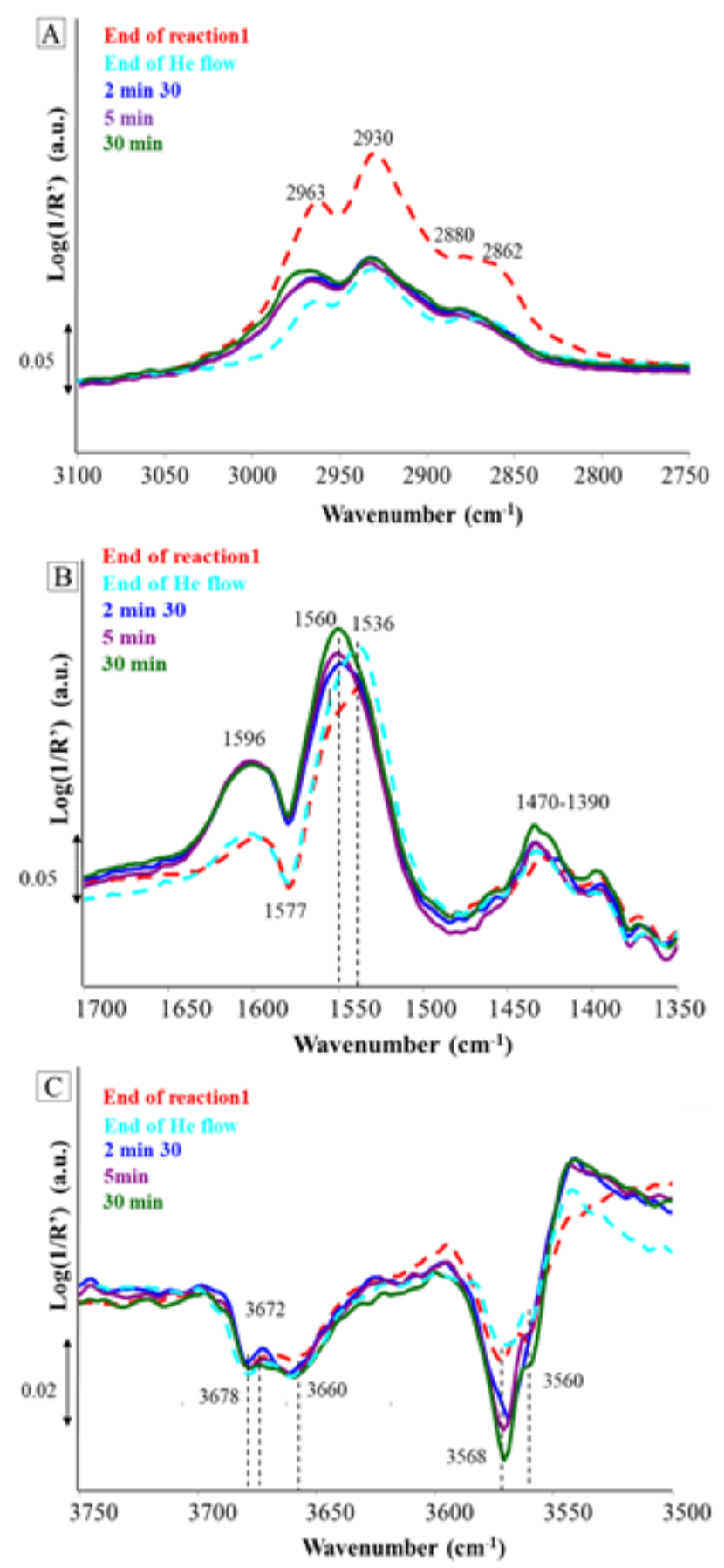

and C). For this latter sample, as the reaction 2 step starts, most carbon polymeric species (bands in the $1500-1670 \mathrm{~cm}^{-1}$ region) suddenly vanished unexpectedly, may be due to an uncontrolled

Figure 12. Difference DRIFT spectra recorded for HAp-S $S_{623 k}$ sample from the beginning of reaction 2 step in the $(A) v_{\mathrm{CH}}(B) v_{\mathrm{CO}}$ and $(\mathrm{C}) v_{\mathrm{OH}}$ regions. 


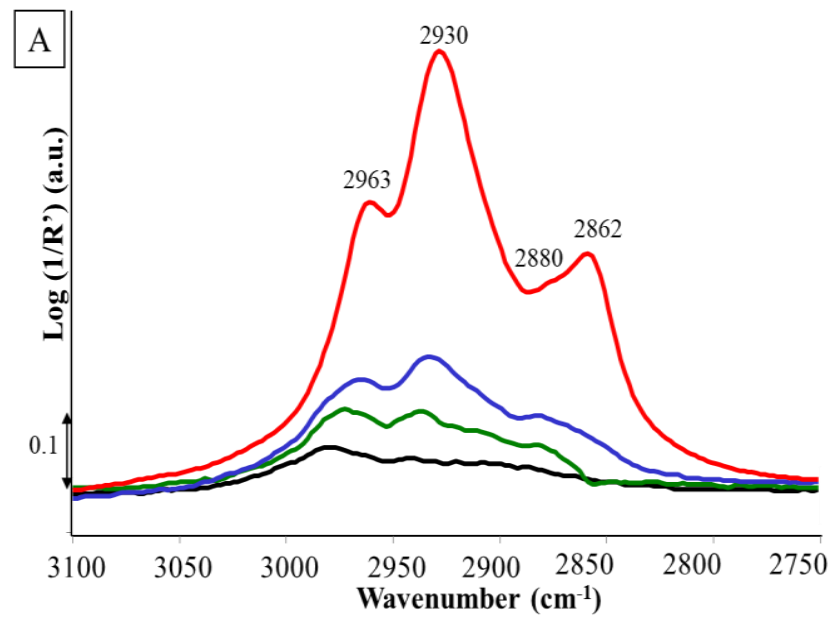

exothermic process. Simultaneously, the underlying surface $\mathrm{POH}$ groups were also suddenly recovered (flat baseline in the corresponding area of the black spectrum in figure $13 \mathrm{C}$ ) and the unidentate calcium carbonate contribution (band at $1577 \mathrm{~cm}^{-1}$ ) disappeared, as shown on the absolute DRIFT spectrum reported in figure $\mathbf{1 4}$ and the absence of the corresponding negative contribution in figure $14 \mathrm{~B}$. More importantly, despite the full regeneration of the $\mathrm{POH}$ and $\mathrm{OH}^{-}$groups for $\mathrm{HAp}-\mathrm{U}_{623} \mathrm{~K}$, the product selectivities related to reaction 2 step once more differ from those obtained during reaction 1 step, with a significant increase in the acetaldehyde production (figure $11 \mathrm{~B}$ ). The IR contribution related to surface basic $\mathrm{OH}^{-}$sites is once again perturbed, with a single negative contribution at $3568 \mathrm{~cm}^{-1}$ (figure $13 \mathrm{C}$ ) and the surface $\mathrm{POH}$ species remain as spectators species during the reaction 2 step, as illustrated by the flat baseline observed in the related regions in figure $13 \mathrm{C}$. Such an increase in acetaldehyde production in reaction 2 step over HAp$\mathrm{U}_{623} \mathrm{~K}$ (figure $11 \mathrm{~B}$ ) can be explained by the prevailing involvement of $\mathrm{Ca}^{2+}$ cations whose accessible amount was strongly increased due to the release of the corresponding unidentate carbonates. Hence, $\mathrm{Ca}^{2+}$ cations acting together with $\mathrm{OH}^{-}$groups (either because $\mathrm{POH}$ groups have been previously poisoned or because their relative amount is increased) favor the formation of acetaldehyde. Such ability of the $\mathrm{Ca}^{2+}-\mathrm{OH}^{-}$pair to favor the formation of acetaldehyde is supported by the previous work of Tsuchida et al. ${ }^{[3 a]}$ in which it was shown that the prevailing formation of acetaldehyde from ethanol was favored on $\mathrm{CaO}$ (that also exposes $\mathrm{Ca}^{2+}-\mathrm{OH}^{-}$pairs under the related operating conditions ${ }^{[31]}$ ). In contrast, $n$-butanol can be formed as long as a fraction of $\mathrm{POH}$ groups keeps on working (reaction 1 step).

How can it be considered that different acidic partners, $\mathrm{Ca}^{2+}$ and $\mathrm{POH}$ species would be involved in the dehydrogenation and aldol condensation key reaction steps? Firstly, the strength of the acidic site partner of the deprotonating basic site plays a key role in basic reactions for the stabilization of the anionic intermediate (here, $\mathrm{Ca}^{2+}$ is a stronger acidic site than $\mathrm{POH}$ sites). More specifically in the case of the aldol condensation, it was underlined that a peculiar acid-base balance is required. ${ }^{[32]}$ Secondly, besides the relative strength, the respective Lewis and Brønsted nature of the two acidic sites needs to be taken into consideration. On the one hand, in the case of dehydrogenation

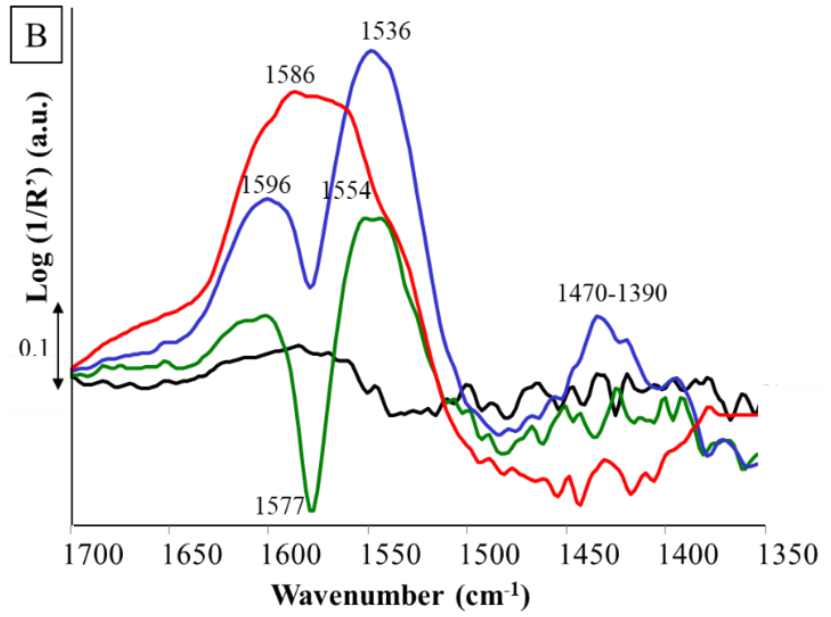

of primary or secondary alcohol (such as isopropanol), both a deprotonating basic site and a Lewis acid site are required to form the alcoolate intermediate and to abstract the hydride ion, respectively. ${ }^{[22 b]}$ On the other hand, Brønsted acid sites were proposed to be involved in the formation of crotonaldehyde from acetaldehyde. ${ }^{[33]}$

Compared to other basic catalytic systems, hydroxyapatite is the only catalyst to exhibit both Lewis $\left(\mathrm{Ca}^{2+}\right)$ and Brønsted (POH) acid sites likely to act as acidic partners of the acid-base pairs involved in the two first steps of $n$-butanol formation, namely the dehydrogenation of ethanol and the aldol condensation steps. In combination with the basic sites, mainly $\mathrm{OH}^{-}$groups under the present operating conditions, but also the few derived $\mathrm{O}^{2-}$ species present when high thermal treatment is performed, these acidic sites provide two acid-base pairs able to form acetaldehyde and to further transform it via hydride aldo condensation. Finally, another key reaction step to produce $n$ butanol from ethanol is the hydrogenation of crotonaldehyde into $n$-butanol. ${ }^{[7 \mathrm{a}]}$ It remains unclear at present whether the recombination of the species (stored on $\mathrm{Ca}^{2+}$ ions) with protons 


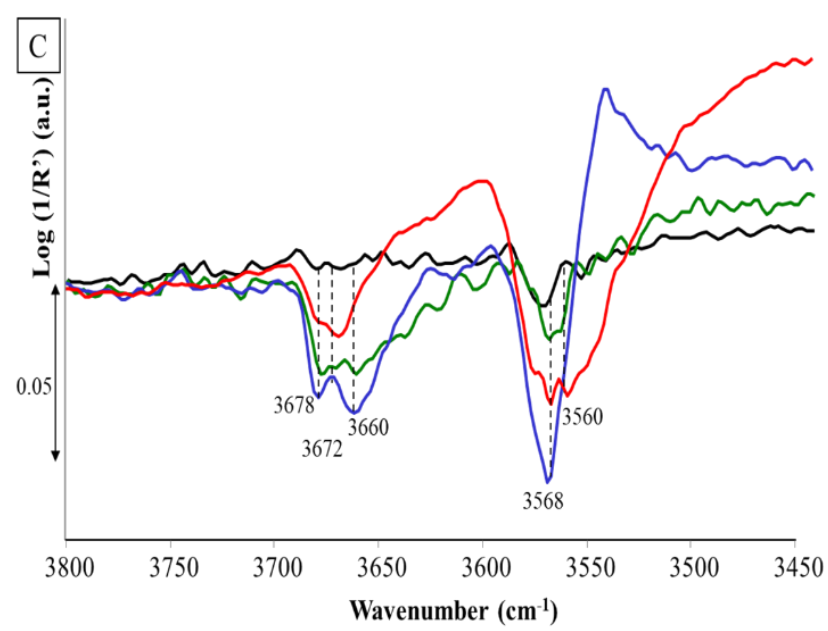

Figure 13. Difference DRIFT spectra recorded for HAp-S $623 \mathrm{k}$ (blue), $\mathrm{HAp}-\mathrm{O}_{623 \mathrm{k}}$ (green), $\mathrm{HAp}-\mathrm{O}_{873 \mathrm{~K}}$ (red) and $\mathrm{HAp}-\mathrm{U}_{623 \mathrm{~K}}$ (black) samples from the beginning of reaction 2 step in the (A) $v_{\mathrm{CH}}$ (B) $v_{\mathrm{CO}}$ and $(\mathrm{C}) v_{\mathrm{OH}}$ regions.

(particularly available for this proton conductor material ${ }^{[25 b]}$ ) may explain the peculiar ability of hydroxyapatite to achieve by itself this last hydrogenation step, whereas other traditional basic systems always require the addition of a metallic function to selectively produce $n$-butanol. If the involvement of MPV-like mechanism is proposed, ${ }^{[10]}$ the role of the proton mobility on the catalytic behavior of hydroxyapatite will also be discussed in a forthcoming paper.

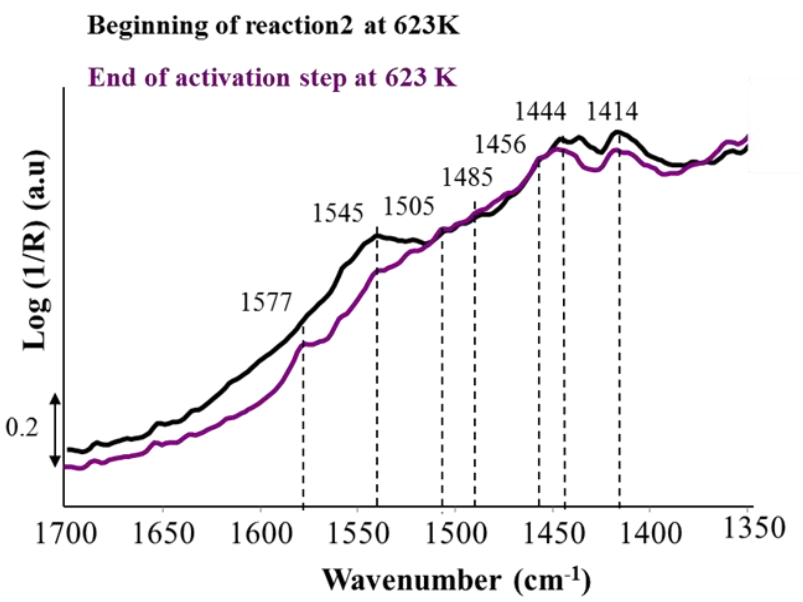

Figure 14. Absolute spectra recorded for $\mathrm{HAp}-\mathrm{U}_{623} \mathrm{~K}$ sample at the end of the activation step and at the beginning of the reaction 2 step in the the $v_{\mathrm{CO}}$ region.

\section{Conclusions}

Operando DRIFT study was carried out to follow the catalytic transformation of ethanol into acetaldehyde and $n$-butanol, and to identify the nature and the role of the active sites. Apart from the formation of positive IR contributions in difference spectra attributed to the presence of strongly-bound carbon polymeric species, responsible for the observed deactivation process, peculiar attention was devoted to the changes in the negative contributions related to the perturbation of surface vibrators. The ability of such sites to be recovered under an $\mathrm{He}$ atmosphere and their consequence on a second reaction step were investigated.
Among the surface sites, unidentate calcium carbonates, terminated $\mathrm{POH}$ and $\mathrm{OH}$ groups emerging from the columns, only the basic $\mathrm{OH}$ groups could be partially or fully (for the most basic ones) regenerated under the $\mathrm{He}$ step, resulting in the partial or full recovery of the initial ethanol conversion during a subsequent second reaction step. This clearly shows that the availability of the basic $\mathrm{OH}^{-}$groups governs the activation of ethanol. The promoting effect of the high activation temperature $(873 \mathrm{~K})$ of HAp on the ethanol conversion measured at $623 \mathrm{~K}$ is ascribed to the presence of few strong $\mathrm{O}^{2-}$ basic sites derived from the dehydroxylation of columnar $\mathrm{OH}^{-}$groups that are involved in the activation of ethanol. The existence of two surface $\mathrm{OH}$ contributions may refer to the involvement of two types of surface $\mathrm{OH}^{-}$groups, with up and down orientations of their protons, that would react differently with their neighboring acidic partners, namely $\mathrm{Ca}^{2+}$ and $\mathrm{POH}$ species. The nature of the acidic sites acting cooperatively with these $\mathrm{OH}^{-}$groups within acid-base pairs required for any basic reaction steps is determinant to control the selectivity in the formed products: 1) $n$-butanol is formed only as long as $\mathrm{POH}$ sites are still available, 2) once the $\mathrm{POH}$ sites have been poisoned (upon intermediate treatment under $\mathrm{He}$ ) and a higher number of $\mathrm{Ca}^{2+}$ species is accessible (resulting from the release of unidentate carbonates), only $\mathrm{Ca}^{2+}$ cations are involved as an acidic partner of the basic $\mathrm{OH}^{-}$groups. Hence, the acid-base pair involved in the transformation of ethanol switches to $\mathrm{Ca}^{2+}-\mathrm{OH}^{-}$during reaction 2 step, and the reaction leads mainly to the formation of acetaldehyde. This not only confirms that acetaldehyde acts as an intermediate in the formation of $n$-butanol, but also indicates that various active sites are involved in the relevant key reaction steps: $\mathrm{Ca}^{2+}-\mathrm{OH}^{-}$and $\mathrm{POH}-\mathrm{OH}^{-}$as acid-base pairs in the dehydrogenation of ethanol to acetaldehyde and the aldol condensation for $n$-butanol formation, respectively. The simultaneous availability of two weak acid-base pairs on a single material, also including Lewis acid sites favoring hydride abstraction to dehydrogenate ethanol and Brønsted acid sites favoring the aldol condensation reaction, makes hydroxyapatite a unique catalytic system able to transform selectively ethanol to $n$-butanol without the need of any metallic function.

\section{Experimental Section}

\section{Sample preparation and characterization}

Hydroxyapatite samples were prepared according to the procedure described previously: ${ }^{[30]}$ the co-precipitation of $\mathrm{Ca}\left(\mathrm{NO}_{3}\right)_{2}$ and $\left(\mathrm{NH}_{4}\right)_{2} \mathrm{HPO}_{4}$ solutions beforehand adjusted at $\mathrm{pH}=$ 10 was performed at $353 \mathrm{~K}$ under a $\mathrm{N}_{2}$ flow to limit carbonation of the materials. As detailed elsewhere ${ }^{[14 \mathrm{~b}]}$ depending on the $\mathrm{pH}$ control procedures, even with a nominal $\mathrm{Ca} / \mathrm{P}$ ratio of 1.67 of the precursors in the solutions, hydroxyapatite samples can be obtained with different $\mathrm{Ca} / \mathrm{P}$ ratios. The three $\mathrm{HAp}$ samples studied in this work have been obtained by periodic, continuous or without addition of $\mathrm{NH}_{4} \mathrm{OH}$ during the precipitation step, respectively. The obtained precipitates were then matured at the same temperature for 4 hours under reflux. The washed precipitates were then dried overnight at $373 \mathrm{~K}$ and thermally 
treated under $\operatorname{Ar}$ flow $\left(150 \mathrm{~mL} \mathrm{~min}{ }^{-1}\right)$ up to $623 \mathrm{~K}\left(5 \mathrm{~K} \mathrm{~min}^{-1}\right)$ for $90 \mathrm{~min}$. In one case, a thermal treatment was also carried out at $873 \mathrm{~K}$. The $\mathrm{Ca} / \mathrm{P}$ ratios measured by ICP-AES analysis ("Service Central d'Analyse" of the CNRS, Solaize, France) were 1.67, 1.77 and 1.64, for the samples prepared with periodic, continuous or without addition of $\mathrm{NH}_{4} \mathrm{OH}$, respectively. The samples will be hereafter referred to as HAp-S $623 \mathrm{k}, \mathrm{HAp}-\mathrm{O}_{623 \mathrm{~K}}$, $\mathrm{HAp}-\mathrm{O}_{873 \mathrm{~K}}$ and $\mathrm{HAp}-\mathrm{U}_{623 \mathrm{~K}}$, respectively, where $\mathrm{S}, \mathrm{O}$ and $\mathrm{U}$ stand for stoichiometric, over-stoichiometric and under-stoichiometric $\mathrm{Ca} / \mathrm{P}$ ratios, respectively, and 623 and $873 \mathrm{~K}$ refer to as the temperatures of final thermal treatment applied for the various samples (the same temperature is further applied for activation step performed prior to catalytic measurements).

X-ray powder diffractograms were recorded with a D8 Advance diffractometer equipped with a Copper anode generator $\left(\lambda=1.5418 \AA\right.$ ) . Diffractograms were recorded by $0.02^{\circ}$ steps in the $2 \theta$ range of $10-85^{\circ}$. The crystalline hydroxyapatite structure of the samples was identified from comparison with the ICDD pattern 01-074-9780(A). Specific surface areas were measured by adsorption of $\mathrm{N}_{2}$ at $77 \mathrm{~K}$ on a Micromeritics (ASAP 2010) apparatus and calculated from the BET method. After thermal treatment at $623 \mathrm{~K}, \mathrm{HAp}-\mathrm{S}_{623} \mathrm{~K}, \mathrm{HAp}-\mathrm{O}_{623 \mathrm{~K}}$ and $\mathrm{HAp}-\mathrm{U}_{623 \mathrm{~K}}$ exhibit specific surface areas of 41,42 and $31 \mathrm{~m}^{2} \mathrm{~g}^{-1}$, respectively. Thermal treatment of sample $\mathrm{HAp}-\mathrm{O}$ at $873 \mathrm{~K}\left(\mathrm{HAp}-\mathrm{O}_{873 \mathrm{~K}}\right)$ leads to a decrease in the specific surface area down to $33 \mathrm{~m}^{2} \mathrm{~g}^{-1}$. The in situ characterization of the acidity of these materials was detailed elsewhere ${ }^{[7 \mathrm{e}]}$ from the adsorption of $\mathrm{CO}$ at $77 \mathrm{~K}$ monitored by infra-red. It was shown that the accessibility of $\mathrm{Ca}^{2+}$ ions exposed at the top surface of HAp-S $\mathrm{S}_{623 \mathrm{~K}}, \mathrm{HAp}-\mathrm{U}_{623 \mathrm{~K}}$, HAp$\mathrm{O}_{623 \mathrm{~K}}$ and $\mathrm{HAp}-\mathrm{O}_{873} \mathrm{k}$ remained quite limited compared to that of terminal $\mathrm{POH}$ groups.

\section{Operando DRIFT experiments}

The HAp samples $(40 \mathrm{mg}$ ) were placed inside a heated crucible located in a Thermo Spectra-Tech high-temperature cell equipped with ZnSe windows and with appropriate gas inlet and outlet connections as to pass the gas flow through the catalytic bed and to ensure homogenous contact between the sample and the flowing gas. ${ }^{[32 a, 34]}$ Successive steps were considered, as summarized in figure 15. After activation, a first reaction step (reaction 1) was carried out for one hour at $623 \mathrm{~K}$. The reactant feed was then switched to He flow for 2 hours, maintaining the temperature at $623 \mathrm{~K}$. Finally, a second reaction step (reaction 2) was carried out at the same temperature.

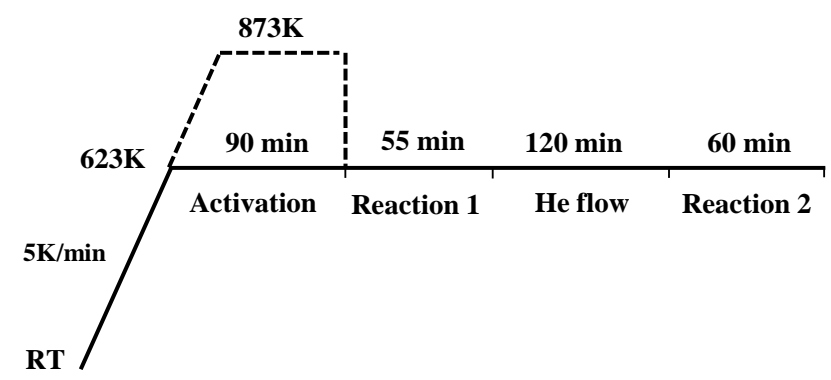

Figure 15. Sequence of successive steps implemented under operando conditions (the dashed line refers to as the pretreatment achieved in the case of $\mathrm{HAp}-\mathrm{O}_{873 \mathrm{~K}}$ ).
The activation of the samples was carried out under helium flow $\left(20 \mathrm{~mL} \mathrm{~min}^{-1}\right)$, heating the sample $\left(5 \mathrm{~K} \mathrm{~min}^{-1}\right)$ up to 623 or $873 \mathrm{~K}$, and maintaining this temperature for $90 \mathrm{~min}$, before switching from the inert flow to the reactant feed. The reactant feed consisted of ethanol diluted in He. Helium $\left(20 \mathrm{~mL} \mathrm{~min}^{-1}\right)$ was bubbled in ethanol (Aldrich, 99.9\%) at $278 \mathrm{~K}$ to achieve a contact

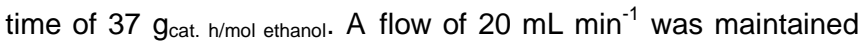
during the intermediate step under $\mathrm{He}$.

The gas phase composition at the exit of the DRIFT cell was analyzed every $5 \mathrm{~min}$ using a two channels micro-gas chromatograph (Varian, CP4900) equipped with PPQ and 5CB columns allowing the separation and the catharometric quantification of light and heavy products, respectively. EtOH conversion and selectivities were calculated as follows: conv $\mathrm{EtOH}_{\mathrm{H}}$ $(\%)=\left(\mathrm{P}_{\text {EtOH }}^{\circ}-\mathrm{P}_{\mathrm{EtOH}}\right) \times 100 / \mathrm{P}^{\circ}{ }_{\mathrm{EtOH}}, \mathrm{Sel}_{\mathrm{i}}(\%)=\alpha_{\mathrm{i}} \mathrm{P}_{\mathrm{i}} \times 100 /\left(\mathrm{P}_{\mathrm{EtOH}}^{\circ}-\right.$ $\mathrm{P}_{\mathrm{EtOH}}$ ), where $\mathrm{P}^{\circ}{ }_{\mathrm{EtOH}}$ is the reference $\mathrm{EtOH}$ pressure measured before reaction, $\mathrm{P}_{\mathrm{EtOH}}$ and $\mathrm{Pi}$ are partial pressures of $\mathrm{EtOH}$ and $\mathrm{i}$ product during the reaction and $\alpha_{i}$ the $1 / 2$ of the number of carbon in the i product.

Diffuse reflectance infrared spectra were recorded in the $4000-1200 \mathrm{~cm}^{-1}$ range $\left(4 \mathrm{~cm}^{-1}\right.$ resolution, 256 scans/spectrum, MCT detector) using a Brüker IFS $66 \mathrm{~V}$ spectrometer every 150 s. A reference spectrum was recorded with $\mathrm{KBr}$ (Fluka, purity > $99.5 \%)$ under the same operating conditions. The absolute spectra recorded at the end of the activation step (623 or $873 \mathrm{~K}$ ) are reported in $\log 1 / \mathrm{R}$ with $\mathrm{R}=\mathrm{I}_{\mathrm{HAp}} / \mathrm{I}_{\mathrm{KBr}}$. The difference DRIFT spectra reported for the successive steps of the sequence are reported in $\log 1 / R^{\prime}$ with the relative reflectance $R^{\prime}=I_{\text {HAp sequence }}$ / $I_{\text {HAp }}$ (spectrum recorded during the successive steps of the sequence / spectrum recorded at 623 or $873 \mathrm{~K}$ at the end of the activation step). ${ }^{[35]}$ The gas phase contribution of ethanol was systematically subtracted for spectra related to the two reaction steps. No significant modification of the shape nor intensity of the P-O combination bands (2200-1950 $\left.\mathrm{cm}^{-1}\right)$ were observed during the successive investigated steps performed at $623 \mathrm{~K}$, which indicates that the optical properties of the samples are not modified during the reaction processes. For comparison purpose, when spectra related to different samples are reported on a same figure, normalization using the P-O combination bands has been systematically applied.

\section{Acknowledgements}

The authors are grateful to Vincent Lhosinho from the Laboratoire de Réactivité de Surface, Sorbonne Université, for his help in the maintenance of the $\mathrm{EtOH}$ and $\mathrm{MBOH}$ reaction setup.

Keywords: $\mathrm{POH} / \mathrm{OH}^{--}$and $\mathrm{Ca}^{2+} / \mathrm{OH}^{-}$acid base pairs - DRIFT. hydroxyapatites $\cdot$ operando

[1] a) G. R. M. Dowson, M. F. Haddow, J. Lee, R. L. Wingad, D. F. Wass, Angew. Chem. Int. Ed. 2013, 52, 9005-9008; b) J. Sun, Y. Wang, ACS Catal. 2014, 4, 1078-1090.

[2] D. L. Carvalho, R. R. d. Avillez, M. T. Rodrigues, L. E. P. Borges, L. G. Appel, Appl. Catal. A Gen. 2012, 415-416, 96100. 
[3] a) T. Tsuchida, T. Yoshioka, S. Sakuma, T. Takeguchi, W Ueda, Ind. Eng. Chem. Res. 2008, 47, 1443-1452; b) N. Savage, Nature 2011, 474, S9-S11.

[4] a) S. Hanspal, Z. D. Young, H. Shou, R. J. Davis, ACS Catal. 2015, 5, 1737-1746; b) C. R. Ho, S. Shylesh, A. T. Bell, ACS Catal. 2016, 6, 939-948.

[5] K. Koda, T. Matsu-ura, Y. Obora, Y. Ishii, Chem. Lett. 2009 38, 838-839.

[6] a) T. Tsuchida, S. Sakuma, T. Takeguchi, W. Ueda, Ind. Eng Chem. Res. 2006, 45, 8634-8642; b) J. T. Kozlowski , R. J. Davis, ACS Catal. 2013, 3, 1588-1600; c) D. Gabriëls, W. Y Hernández, B. Sels, P. Van Der Voort, A. Verberckmoes, Catal. Sci. Technol. 2015, 5, 3876-3902.

[7] a) T. Tsuchida, J. Kubo, T. Yoshioka, S. Sakuma, T. Takeguchi, W. Ueda, J. Catal. 2008, 259, 183-189; b) S. Ogo, A. Onda, Y. K., Appl. Catal. A 2011, 402, 188-195; c) J. Scalbert, F. Thibault-Starzyk, R. Jacquot, D. Morvan, F. Meunier, J. Catal. 2014, 311, 28-32; d) L. Silvester, J. F. Lamonier, Faye, J., M. Capron, R. N. Vannier, C. Lamonier, J. L. Dubois, J. L. Couturier, C. Calais, F. Dumeignil, Catal. Sci. Technol. 2015, 5, 2994-3006; e) M. Ben Osman, S. Diallo Garcia, J. M. Krafft, C. Methivier, J. Blanchard, T. Yoshioka, J. Kubo, G. Costentin, Phys. Chem. Chem. Phys. 2016, 18, 2783 -27847 .

[8] M. Guerbet, C.R. Chimie 1909, 149, 129.

[9] a) S. Veibel, J. I. Nielsen, Tetrahedron 1967, 213, 1723-1733 b) A. J. O'Lenick, J. Surfact. Deterg. 2001, 4, 311-315; c) C. Carlini, M. Di Girolamo, A. Macinai, M. Marchionna, M. Noviello, A. M. Raspolli Galletti, G. Sbrana, J. Mol. Catal. 2003, 200, 137-146.

[10] Z. D. Young, R. J. Davis, Catal. Sci. Technol. 2018, 8, 17221729.

[11] M. J. L. Gines, E. Iglesia, J. Catal. 1998, 176, 155-172.

[12] a) S. Sugiyama, Y. Iguchi, T. Minami, H. Hayashi, J. B. Moffat Catal. Lett. 1997, 46, 279-285; b) S. Sugiyama, E. Nitta, H. Hayashi, J. B. Moffat, Catal. Lett. 1999, 59, 67-72; c) S. Sugiyama, T. Osaka, Y. Hirata, K. I. Sotowa, Appl. Catal. A 2006, 312, 52-58

[13] a) S. J. Joris, C. H. Amberg, J. Phys. Chem. 1971, 75, 31673171; b) H. Monma, J. Catal. 1982, 75, 200-203; c) M.

Zahouily, Y. Abrouki, B. Bahlaouan, A. Rayadh, S. Sebti, Catal. Commun. 2003, 4, 521-524; d) S. Sebti, A. Solhy, R. Tahir, A. Smahi, Appl. Catal. A 2002, 235, 273-281; e) A. Solhy, J. H. Clark, R. Tahir, S. Sebti, M. Larzek, Green Chem. 2006, 8 , 871-874.

[14] a) T. Tsuchida, J. Kubo, T. Yoshioka, S. Sakuma, T. Takeguchi, W. Ueda, J. Jap. Petrol. Inst. 2009, 52; b) M. Ben Osman, J. M. Krafft, Y. Millot, F. Averseng, T. Yoshioka, J. Kubo, G. Costentin, Eur. J. Inorg. Chem. 2016, 2016(17), 2709-2720.

[15] a) S. Ogo, A. Onda, K. Yanagisawa, Appl. Catal. A 2008, 348, 129-134; b) L. Silvester, J. F. Lamonier, R. N. Vannier, C. Lamonier, M. Capron, A. S. Mamede, F. Pourpoint, A Gervasini, F. Dumeignil, J. Mater. Chem. A 2014, 2, 1107311090; c) B. Yan, L. Z. Tao, Y. Liang, B. Q. Xu, ACS Catal. 2014, 4, 1931-1943; d) V. C. Ghantani, S. T. Lomate, M. K. Dongare, S. B. Umbarkar, Green Chem. 2013, 15, 1211-1217. Yasukawa, S. Ouchi, K. Kandori, T. Ishikawa, J. Mater. Chem. 1996, 6, 1401-1405; c) N. Cheikhi, M. Kacimi, M. Rouimi, M.

Ziyad, L. F. Liotta, G. Pantaleo, G. Deganello, J. Catal. 2005, 232, 257-267.

S. Diallo-Garcia, M. Ben Osman, J. M. Krafft, S. Casale, C Thomas, J. Kubo, G. Costentin, J. Phys. Chem. C 2014, 118 12744-12757.

a) S. Diallo-Garcia, M. Ben Osman, J. M. Krafft, S. Boujday, G. Costentin, Catal Today 2014, 226, 81-88; b) M. Ben Osman,

S. Diallo-Garcia, V. Herledan, T. Yoshioka, K. Kubo, Y. Millot, G. Costentin, J. Phys. Chem. C 2015, 119, 23008-23020.

G. Costentin, J. Phys. Chem. C 2015, 119, 23008-23020. Krafft, P. Bazin, J. Saussey, M. Che, Catal. Today 2006, 116, 196-205.

C. A. Ospina, J. Terra, A. J. Ramirez, M. Farinac, D. E. Ellis, A. M. Rossi, Colloids and Surfaces B: Biointerfaces 2012, 89, 1522.

a) R. M. Wilson, J. C. Elliot, S. E. P. Dowker, J.Solid State Chem. 2003, 174, 132-140; b) M. Jarlbring, D. E. Sandström,

O. N. Antzutkin, W. Forsling, Langmuir 2006, 22, 4787-4792.

a) H. Lauron-Pernot, F. Luck, J. M. Popa, Appl. Catal. A. Gen 1991, 78, 213-225 ; b) H. Lauron-Pernot, Catal. Rev. 2006, 48 , 315-361.

S. Hanspal, D. Young, J. T. Prillaman, R. J. Davis, J. Catal. 2017, 352, 182-190.

R. Philipp, K. Fujimoto, J. Phys. Chem. 1992, 96, 9035-9038 a) C. Rey, J. C. Trombe, G. Montel, J. Inorg, Nucl. Chem. 1978, 40, 27-30; b) S. Nakamura, H. Takeda, K. Yamashita, J. Appl. Phys. 2001, 89, 5386; c) M. Yashima, Y. Yonehara, H. Fujimori, J. Phys. Chem. C 2011, 115, 25077-25087; d) N. Horiuchi, M. Nakamura, A. Nagai, K. Katayama, K. Yamashita, J. Appl. Phys. 2012, 112, 074901-074906.

a) N. W. Cant, J. A. S. Bett, G. R. Wilson, W. K. Hall, Spectrochim. Acta 1971, 27A, 425-439; b) F. Freund, R. M. Knobel, J.C.S. Dalton 1977, 1136-1140.

a) S. Sugiyama, H. Hayashi, Int. J. Modern Physics B 2003, 17, 1476-1481; b) S. Sugiyama, T. Shono, D. Makino, T. Moriga, H. Hayashi, J. Catal. 2003, 214, 8-14.

a) T. W. Birky, J. T. Kozlowski, R. J. Davis, J. Catal. 2013, 298, 130-137; b) H. Idriss, Platinum Metals Review 2004, 48, 105 115 ; c) R. M. B. Faria, D. V. Cesar, V. M. M. Salim, Catal Today 2008, 133-135, 168-173.

J. Datka, Z. Sarbak, R. P. Eischens, J. Catal. 1994, 145, 544550.

S. Diallo-Garcia, D. Laurencin, J. M. Krafft, S. Casale, M. E. Smith, H. Lauron-Pernot, G. Costentin, J. Phys. Chem. C 2011, 115, 24317-24327.

H. Petitjean, J. M. Krafft, M. Che, H. Lauron Pernot, G. Costentin, Phys Chem Chem Phys 2010, 12, 14740-14748 a) J. F. Groust, G. Costentin, J. M. Krafft, P. Massiani, Phys. Chem. Chem. Phys. 2010, 12, 937-946; b) Y. C. Chang, A. N. Ko, Appl. Catal. A 2000, 190, 149-155; c) V. V. Ordomsky, V. L. Sushkevich, I. I. Ivanova, J. Mol. Catal. A 2010, 333, 85-93. A. I. Biaglow, J. Sepa, R. J. Gorte, D. White, J. Catal. 1995, 151, 373-384.

C. Drouilly, J. M. Krafft, F. Averseng, H. Lauron-Pernot, D. Bazer-Bachi, C. Chizallet, V. Lecocq, Catal. Today 2013, 205, 67-75.

J. Sirita, S. Phanichphant, F. C. Meunier, Anal. Chem. 2007, 79, 3912-3918. 


\section{Electronic Supplementary Information}

\section{ESI 1: MBOH reaction}

The conversion of 2-methylbut-3-yn-1-ol (MBOH) model reaction ${ }^{[1]}$ was used to characterize the acid base properties of the hydroxyapatite samples. The reaction was carried out in gas phase, using an automated differential flow micro-reactor. The catalyst (50 mg) was placed -a fritted disk, in the center of a $U$ shape reactor of $10 \mathrm{~mm}$ internal diameter. The temperature of the catalyst bed was controlled by a thermocouple located close to the wall of the quartz reactor. Samples were firstly pre-treated under a nitrogen flow $\left(20 \mathrm{~mL} \cdot \mathrm{min}^{-1}\right)$ up to $623 \mathrm{~K}$ or $873 \mathrm{~K}(5 \mathrm{~K}$ $\min ^{-1}$ ) for $90 \mathrm{~min}$, before the temperature was decreased to reaction temperature, $413 \mathrm{~K}$. The reactant feed, obtained by bubbling nitrogen $\left(50 \mathrm{~mL} \mathrm{~min}^{-1}\right)$ in liquid $\mathrm{MBOH}$ (Fluka, 99.9\%) at 293 $\mathrm{K}(\mathrm{MBOH}$ partial pressure of $1.73 \mathrm{kPa})$, was then contacted to the catalyst. Reaction products were analyzed every 2 min using a micro GC chromatograph equipped with a CPWAX 52 CB column. For a set of comparison, the reported conversions were normalized to account for the different specific surface areas (Figure S1a).

Over the hydroxyapatites samples investigated, the $\mathrm{MBOH}$ was exclusively converted to acetone and acetylene (with an equimolar ratio). This attests from the basic reactivity of the related surfaces (involving an acid-base pair) as also reported earlier under similar conditions. ${ }^{[2]}$ In these conditions, the $\mathrm{MBOH}$ conversion level can directly be used to rank the samples as a function of their basic character that is mainly governed by the amount and the strength of the basic sites. After activation at $623 \mathrm{~K}$, the conversion obtained for the HAp- $\mathrm{S}_{623 \mathrm{~K}}$ sample (conv=72\%) is found to be significantly greater than that measured for the HAp- $\mathrm{O}_{623} \mathrm{~K}(\mathrm{conv}=54 \%)$ and $\mathrm{HAp}-\mathrm{U}_{623} \mathrm{~K}$ 
$($ conv $=5 \%)$ respectively. This ranking is the same as that obtained for ethanol conversion. Such a tendency confirms the correlation between the conversion of the two alcohols molecules evidenced previously. ${ }^{[3]}$

Increasing the activation temperature to $873 \mathrm{~K}$ not only results in a decrease of the specific surface area of the HAp-O sample, but also in a significantly increase in the $\mathrm{MBOH}$ conversion for HAp- $\mathrm{O}_{873} \mathrm{k}(90 \%)$. As discussed above, an increase in the ethanol was also observed on this sample.

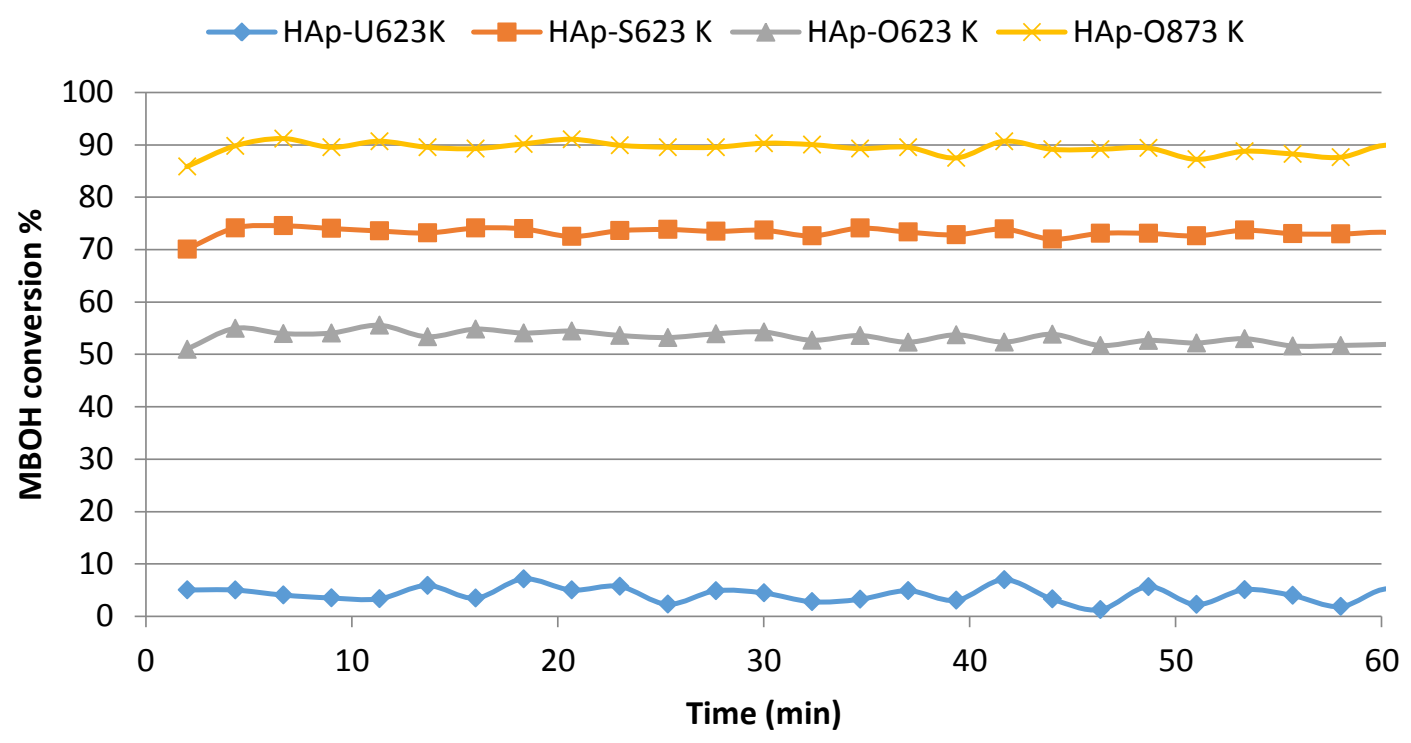

Figure S1a: Normalized conversion of $\mathrm{MBOH}$ as a function of time on stream for the different samples activated either at 623 or $873 \mathrm{~K}$.

As it is the case for the transformation of $\mathrm{EtOH}$, the $\mathrm{MBOH}$ reaction was also followed under operando conditions by DRIFT spectroscopy, using the same set-up as that described for EtOH conversion in the experimental section. Firstly it can be seen that surface $\mathrm{OH}$ groups emerging from the channels are clearly perturbed, with the same splitting observed as that found in the case of the EtOH reaction (negative bands at 3570 and $3562 \mathrm{~cm}^{-1}$, Figure $\mathrm{S} 1 \mathrm{~b}$ ). In addition, the $\mathrm{POH}$ region is also perturbed and similar feature than with $\mathrm{EtOH}$ is observed for the contribution at 
higher wavenumber $\left(3680 \mathrm{~cm}^{-1}\right)$ : despite of lower relative intensity on the absolute spectrum on the pretreated sample (figure 1C), the perturbation of the related contribution is comparatively more intense than that of the band at $3674 \mathrm{~cm}^{-1}$. Note that the $2 \mathrm{~cm}^{-1}$ blue-shift of these bands compared to those reported for the EtOH reaction can be ascribed to the lower reaction temperature for $\mathrm{MBOH}$ (413 K) compared to EtOH (623 K).

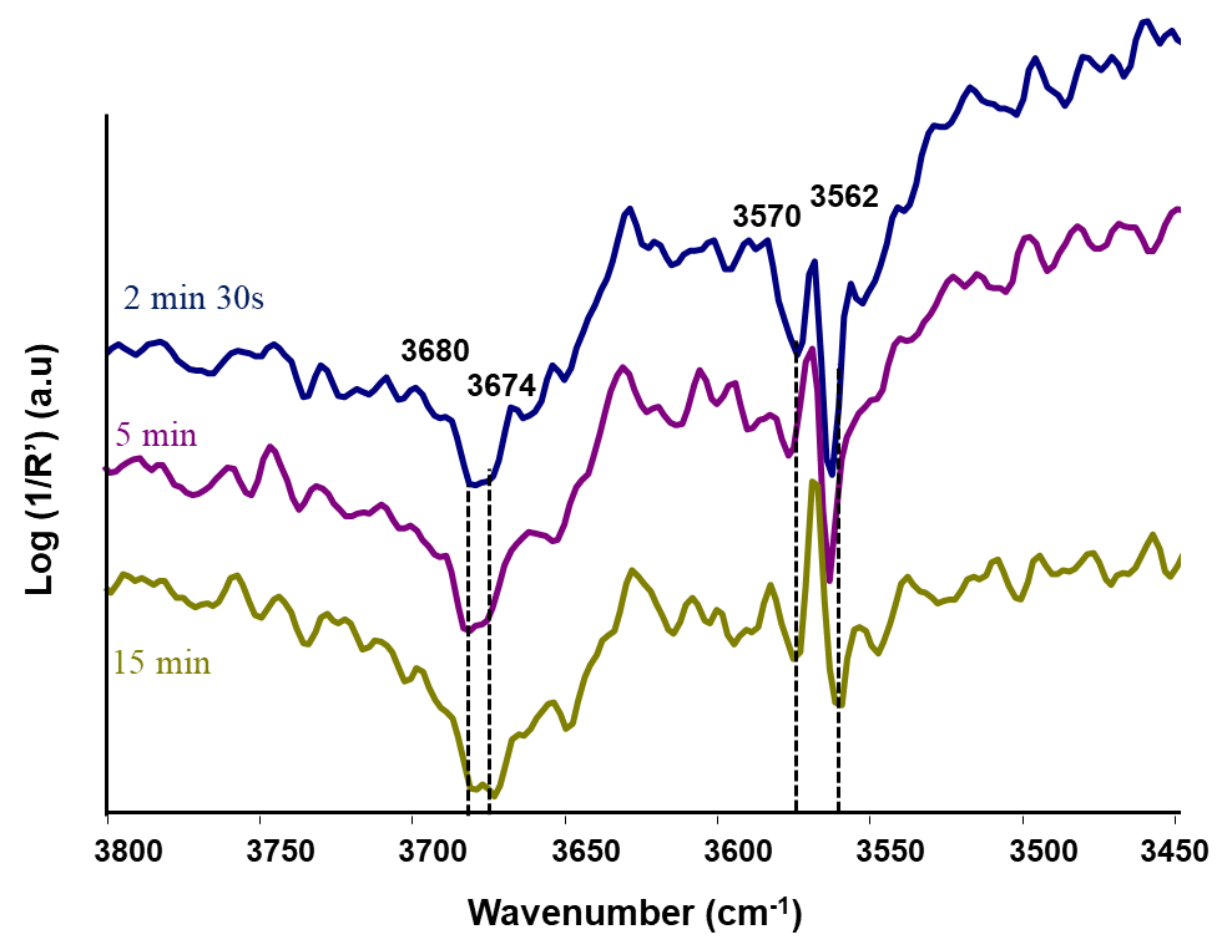

Figure S1b: Difference DRIFT spectra recorded during the $\mathrm{MBOH}$ reaction on $\mathrm{HAp}-\mathrm{S}_{623 \mathrm{~K}}$. 
ESI 2: DRIFT operando spectra recorded upon the three successive steps on $\mathrm{HAp}-\mathrm{O}_{873}$

K•

Figure S2 shows that the tendencies observed on HAp- $\mathrm{O}_{873} \mathrm{~K}$ are essentially the same as those detailed in the case of the HAp-S $\mathrm{S}_{623 \mathrm{~K}}$ sample (Figures 4,8 and 12). 

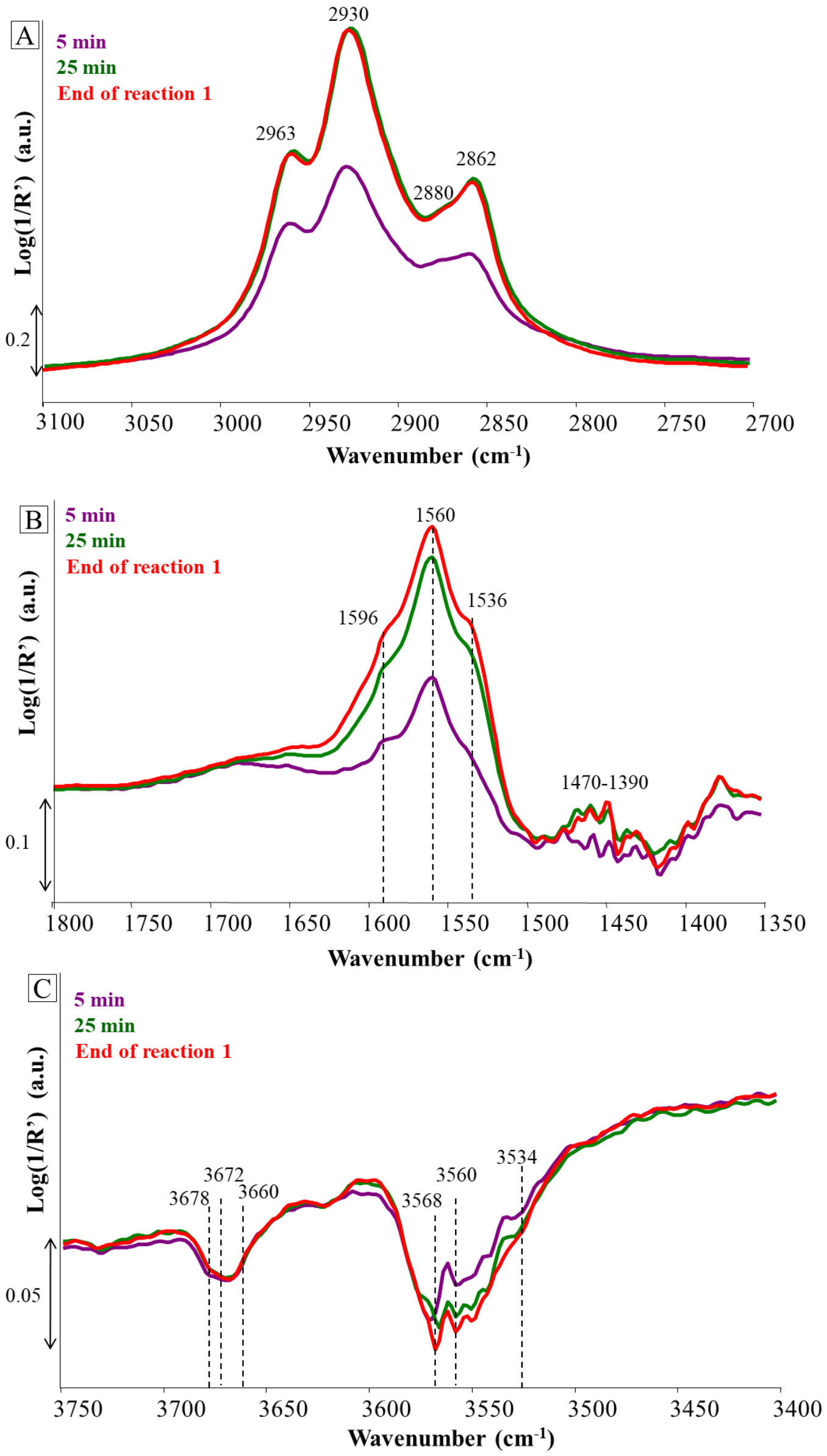

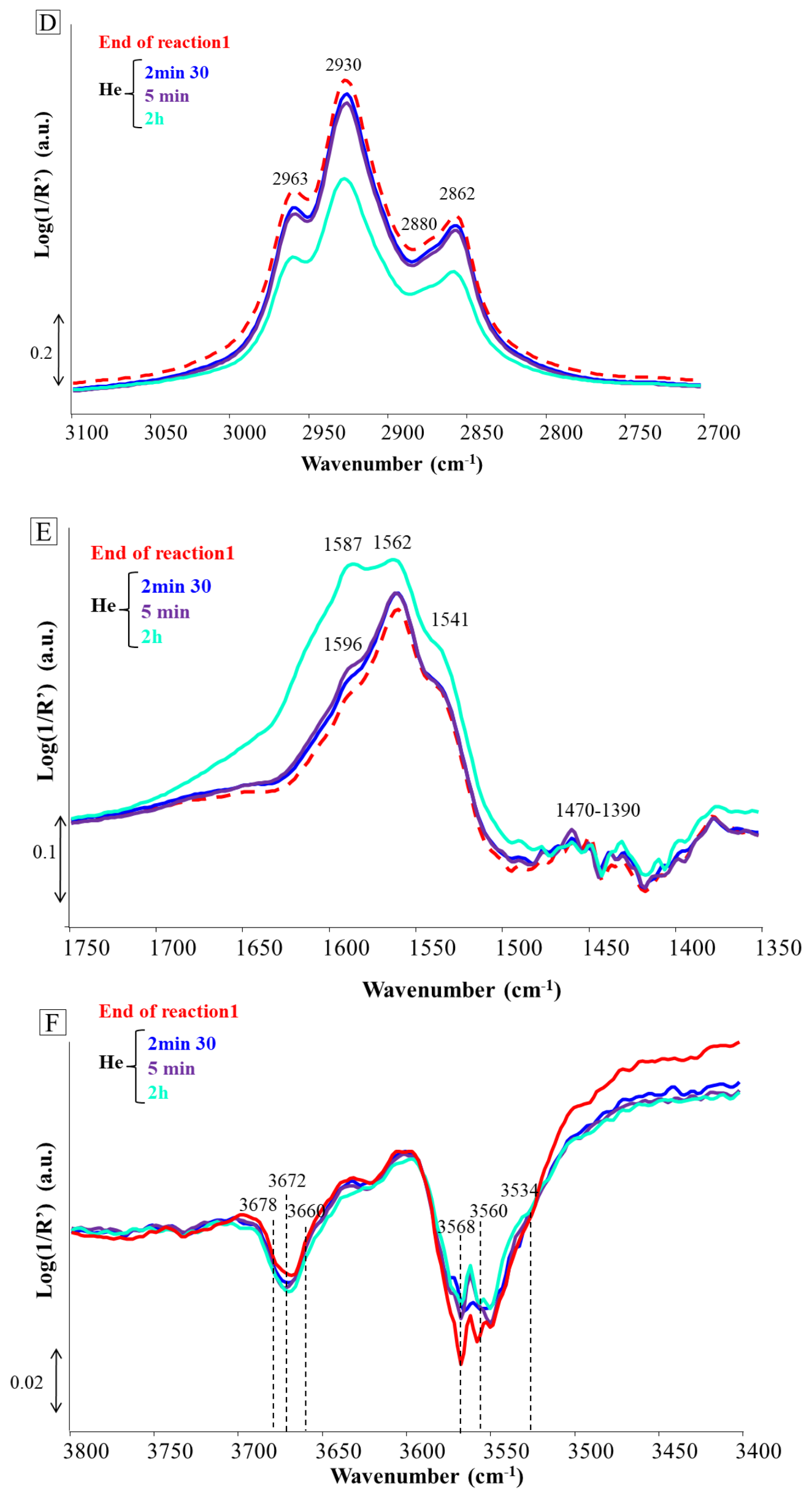

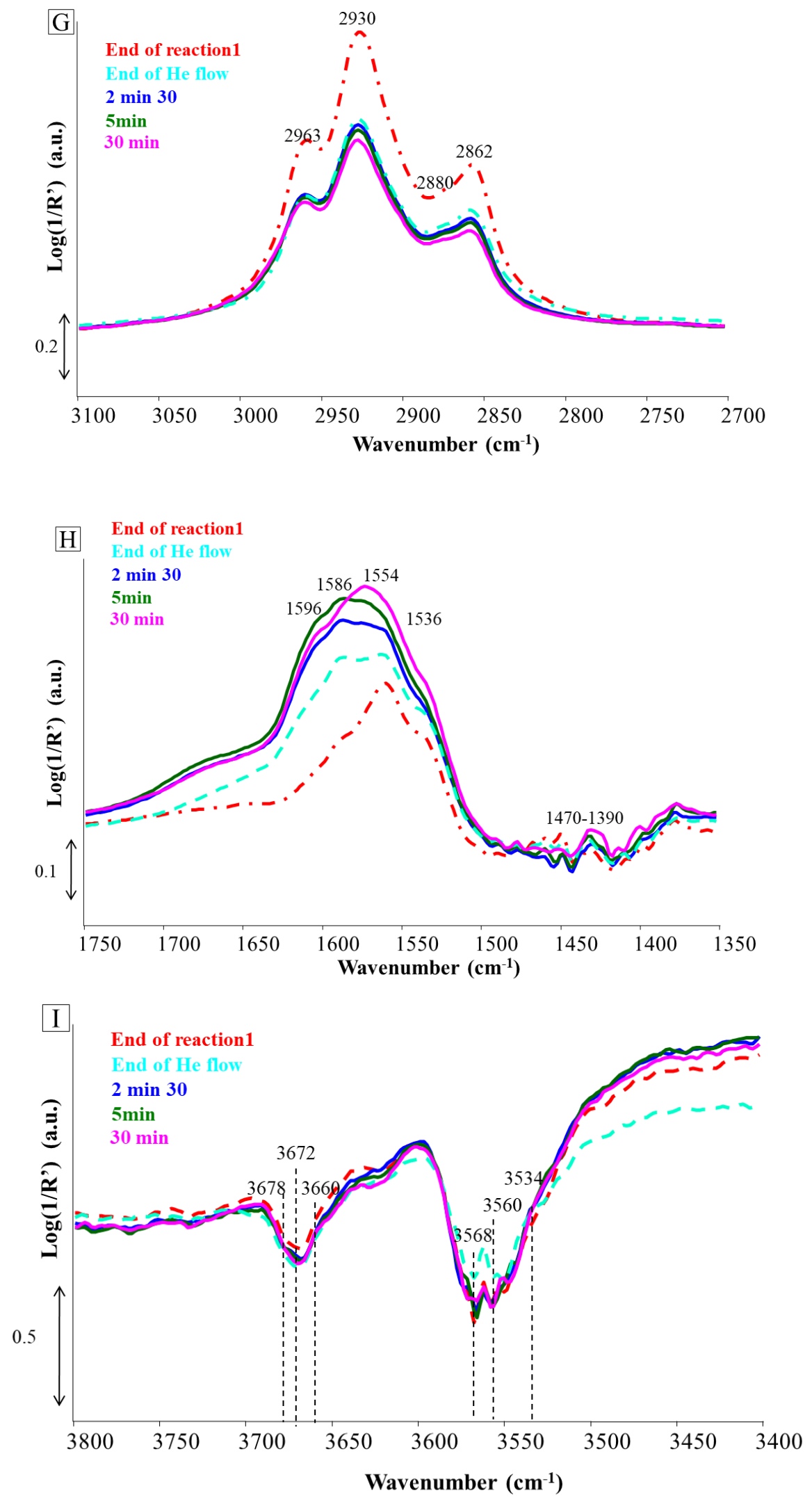
Figure S2: Difference DRIFT spectra obtained for HAp- $\mathrm{O}_{873} \mathrm{~K}$ recorded A), B) and C) during the reaction 1 step, D), E) and F) under He flow and, G), H) and I) during reaction 2 step in the $v_{\mathrm{C}-\mathrm{H}}$, $v_{\mathrm{CO}}$, and $v_{\mathrm{OH}}$ regions.

[1] aH. Lauron-Pernot, F. Luck, J. M. Popa, Appl. Catal. A. Gen 1991, 78, 213-225 ; bH. Lauron-Pernot, Catal. Rev. 2006, 48, 315-361.

[2] aM. Ben Osman, J. M. Krafft, Y. Millot, F. Averseng, T. Yoshioka, J. Kubo, G. Costentin, Eur. J. Inorg. Chem. 2016, 2709-2720; bS. Diallo-Garcia, D. Laurencin, J. M. Krafft, S. Casale, M. E. Smith, H. Lauron-Pernot, G. Costentin, J. Phys. Chem. C 2011, 115, 2431724327.

[3] M. Ben Osman, S. Diallo Garcia, J. M. Krafft, C. Methivier, J. Blanchard, T. Yoshioka, J. Kubo, G. Costentin, Phys. Chem. Chem. Phys. 2016, 18, 2783 -27847. 